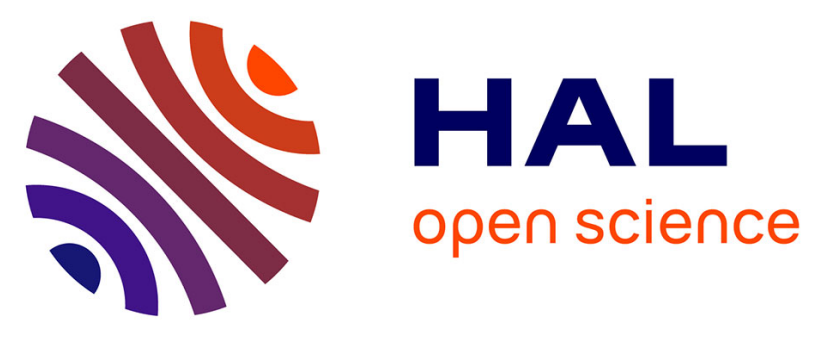

\title{
Conformational Analysis of Hexapseudopeptides Mimicking Reverse Turn Structures Induced by a Modified (S)-Proline. A Combined Spectroscopic and Molecular Dynamics Investigation. Part 4
} Andrea Bottoni, Daniele Balducci, Matteo Calvaresi, Gianni Porzi

\section{To cite this version:}

Andrea Bottoni, Daniele Balducci, Matteo Calvaresi, Gianni Porzi. Conformational Analysis of Hexapseudopeptides Mimicking Reverse Turn Structures Induced by a Modified (S)-Proline. A Combined Spectroscopic and Molecular Dynamics Investigation. Part 4. Molecular Physics, 2009, 107 (07), pp.653-663. 10.1080/00268970902845339 . hal-00513269

\author{
HAL Id: hal-00513269 \\ https://hal.science/hal-00513269
}

Submitted on 1 Sep 2010

HAL is a multi-disciplinary open access archive for the deposit and dissemination of scientific research documents, whether they are published or not. The documents may come from teaching and research institutions in France or abroad, or from public or private research centers.
L'archive ouverte pluridisciplinaire $\mathbf{H A L}$, est destinée au dépôt et à la diffusion de documents scientifiques de niveau recherche, publiés ou non, émanant des établissements d'enseignement et de recherche français ou étrangers, des laboratoires publics ou privés. 


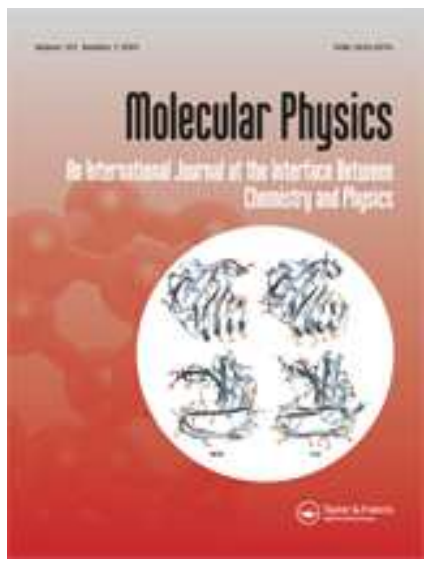

\section{Conformational Analysis of Hexapseudopeptides Mimicking Reverse Turn Structures Induced by a Modified (S)-Proline. A Combined Spectroscopic and Molecular Dynamics Investigation. Part 4}

\begin{tabular}{|c|c|}
\hline Journal: & Molecular Physics \\
\hline Manuscript ID: & TMPH-2009-0033.R1 \\
\hline Manuscript Type: & Full Paper \\
\hline $\begin{array}{r}\text { Date Submitted by the } \\
\text { Author: }\end{array}$ & 18-Feb-2009 \\
\hline Complete List of Authors: & $\begin{array}{l}\text { bottoni, andrea; University of Bologna, Department of Chemistry } \\
\text { Balducci, Daniele; University of Bologna, Department of Chemistry } \\
\text { Calvaresi, Matteo; University of Bologna, Department of Chemistry } \\
\text { Porzi, Gianni; University of Bologna, Department of Chemistry; } \\
\text { University of Bologna, Department of Chemistry }\end{array}$ \\
\hline Keywords: & $\begin{array}{l}\text { Conformational analysis, molecular dynamics, unnatural } \\
\text { hexapeptides, cluster analysis, NMR spectroscopy }\end{array}$ \\
\hline
\end{tabular}

\section{ScholaroNE \\ Manuscript Central}




\begin{abstract}
The structure of unnatural hexapeptides 1, 2a and $\mathbf{2 b}$ containing three $L$-valine units and three unnatural $\alpha$-amino acids ((2R)-methyl aspartic acid, (2S)-methylornitine and modified proline), has been elucidated using ${ }^{1} \mathrm{H}-\mathrm{NMR}$ and IR spectroscopy and a conformational analysis based on molecular dynamics (MD) and cluster analysis. The MD analysis, which provides conformer populations and hydrogen bond lifetimes, is in good agreement with the ${ }^{1} \mathrm{H}-\mathrm{NMR}$ and IR data.
\end{abstract}

\title{
1. Introduction
}

Interaction between peptides and proteins is an essential aspect of many biological processes. The recognition process usually involves the $\beta$-turn as a common structural motif that features the peptide chain. ${ }^{1-3}$ Structural studies revealed that this structure characterizes small peptides functioning as hormones, ${ }^{4-6}$ neurotransmitters ${ }^{7}$ or having other regulatory roles in the organism. The classic $\beta$-turn is stabilized by an intra-molecular hydrogen bond between the carbonyl oxygen of residue $i$ and the amide hydrogen of residue $i+3$, thus forming a typical structural arrangement corresponding to a ten-member ring. ${ }^{1}$ Because this structural organization is associated with the binding process between peptide ligands and receptor targets, it becomes source of biological activity and is involved in the development of several diseases. Thus, it is not surprising that a lot of effort is put in the design and synthesis of peptidomimetics (mimicking $\beta$-turn structures) as new therapeutic agents. ${ }^{8-10}$ The importance of replacing natural amino acids in peptides with non-proteinogenic counterparts, in order to obtain drug-like target molecules, has roused a substantial interest in undertaking the synthesis of new peptidomimetic structures that can exhibit therapeutic effects similar to those of natural peptides but with the advantage of metabolic stability (especially proteolitic stability). Common structural modifications that feature these new peptidomimetics usually involve the incorporation of non-natural amino acids in the peptide chain or the use of altered backbones. ${ }^{11,12}$ 
Proline residues frequently occur in reverse turns and this is presumably due to their unique restricted $\phi$ angle, which is entropically favourable for turn folding. ${ }^{13-15}$ In a recent paper, we reported on the synthesis of pseudo-tetrapeptides containing two $L$-valine units and two modified $\alpha$-amino acids derived from proline and aspartic acid. The conformational analysis carried out on these unnatural peptides, pointed out the role of proline derivatives in originating $\beta$ - and $\gamma$-folded conformers, thus acting as a scaffold promoting compact conformations. ${ }^{16}$

In the present paper our aim is to study more extended unnatural peptides, containing in the middle of the chain a modified $(S)$-proline unit as a scaffold and to investigate the presence of stable conformations associated with reverse turn formation through intra-molecular hydrogen bonds, similar to those already observed. ${ }^{16-18}$ We have synthesized new non-proteinogenic peptides incorporating, besides the modified $(S)$-proline, three $L$-valine units and two additional non proteinogenic $\alpha$-aminoacids such as $(2 R)$-methyl aspartic acid and (2S)-methylornitine. These unnatural hexapeptides (1, $\mathbf{2 a}$ and $\mathbf{2} \mathbf{b}$ in Scheme 1) have been examined using spectroscopic techniques ( ${ }^{1} \mathrm{H}$ NMR and IR) and computational simulations based on molecular dynamics (MD).

(Scheme 1 here)

\section{Experiment}

The synthesis of $\mathbf{1}, \mathbf{2 a}$ and $\mathbf{2 b}$ was accomplished starting from the chiral synthon $\mathbf{3}$ (the mono-lactim ether shown in Scheme 2 and easily obtained from $L$-valine ${ }^{19}$ ) and is described in details in the supplementary material.

\section{(Scheme 2 here)}

${ }^{1} \mathrm{H}$ and ${ }^{13} \mathrm{C}$ NMR spectra were recorded on a Gemini spectrometer at $300 \mathrm{MHz}$ (in about $15 \mathrm{mM}$ solutions) using $\mathrm{CDCl}_{3}$ as solvent. Chemical shifts are reported in ppm relative to $\mathrm{CDCl}_{3}$ while the coupling constants $(J)$ are in Hz. IR spectra were recorded on a Nicolet FT 380 spectrophotometer. Optical rotation values were measured at $25^{\circ} \mathrm{C}$ on a Perkin-Elmer 343 polarimeter. Dry THF was distilled from sodium benzophenone ketyl. Chromatographic separations were performed with silica gel 60 (230-400 mesh).

The synthesis and spectroscopic data of compounds $\mathbf{3}$ and other reaction intermediates are reported in refs 16 and 20,21 .

\section{Computational procedure}

The 3D molecular structures were built using the CORINA package. ${ }^{22,23}$ All calculations were performed at the molecular mechanics (MM) level with the amber 8.0 program. ${ }^{24}$ Simulations were carried out using the Gaff force field. ${ }^{25}$ The AM1-BCC method, ${ }^{26,27}$ as implemented in the 
Antechamber ${ }^{28}$ package, was employed to assign charges to atoms. Solvation effects were taken into account using the Generalized Born Model. ${ }^{29,30}$ The Generalized Born Model has been shown to accurately reproduce relative free energies of different peptide conformations ${ }^{31}$ and to identify correctly the native state of several proteins in an extensive comparison with large decoy sets. ${ }^{32}$ Many recent studies have used molecular dynamics simulations to study small polypeptides. ${ }^{33-36}$ Thus, dynamics were carried out with a dielectric constant $\varepsilon=4.9$ to simulate the electrostatic effects of chloroform (the solvent where ${ }^{1} \mathrm{H}$ NMR data have been recorded). To locate the lowest energy structure, without being trapped in local minima, we first employed a preliminary quenched molecular dynamics (QMD) simulation where the molecules were heated from 0 to $600 \mathrm{~K}$ in $100 \mathrm{ps}$ and then, a trajectory of $10 \mathrm{~ns}$ was carried out at constant temperature $(600 \mathrm{~K})$ and constant pressure (1 atm) with an integration step of $2 \mathrm{fs}$. The $\mathrm{SHAKE}^{37}$ algorithm was used to constrain the stretching of bonds involving hydrogen atoms. The coordinates of the pseudopeptides were saved

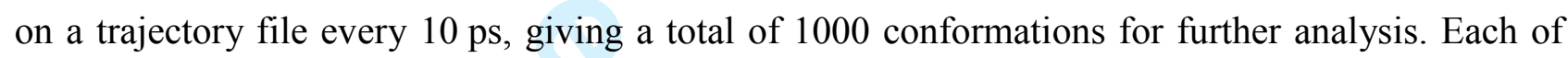
the so obtained structures was energy minimized till the root mean square of the Cartesian elements of the gradient was less than $0.001 \mathrm{kcal} \mathrm{mol}^{-1}$ using a full conjugate gradient minimization and the GB/SA model. ${ }^{38}$ This preliminary simulation provided the best starting structure for a new molecular dynamics at $300 \mathrm{~K}$ to identify intramolecular hydrogen bonds and examine the conformational space of the pseudopeptides at ambient temperature. These dynamics were carried out for $10 \mathrm{~ns}$ using a time step of 0.002 ps (using SHAKE algorithm to constrain the stretching of bonds involving hydrogen atoms) and writing the coordinates every 2 ps on a trajectory file. We analyzed this file with the 'ptraj' package (an AMBER module) ${ }^{24}$ to obtain an estimate of the percentage of the existence of every H-bond during the whole simulation (an "active" hydrogen bond requires a distance between acceptor and donor shorter than $4 \AA$, and a bond angle larger than $\left.90^{\circ}\right)$. We denote this quantity as "lifetime" of a given H-bond even if this term is expressed as a percentage and does not exactly correspond to the usual definition of lifetime given in physical processes. To identify and visualize the most important conformations of the peptides, we carried out a cluster analysis. For this purpose, the $\mathrm{MMTSB}^{39}$ toolset was used. We clustered the conformations obtained from the dynamics on the basis of structural similarity (using ' $\mathrm{kclust}$ ' and a fixed radius clustering of $2.0 \AA$ on Cartesian coordinate RMSD of heavy atoms and hydrogen atoms involved in hydrogen bonds). Clusters were grouped together, if possible, on the basis of the similarity of the hydrogen bond pattern. For each set of clusters the most populated structures have been selected as the representative conformations of each pseudopeptide. 


\section{Results and discussion.}

${ }^{1}$ H-NMR and IR studies. Spectroscopic ${ }^{1} \mathrm{H}-\mathrm{NMR}$ and IR studies were carried out to investigate the structural features of pseudo-hexapeptides 1, 2a and $\mathbf{2 b}$. The chemical shifts of the amidic protons do not exhibit concentration dependence, suggesting that these structures are not involved in intermolecular hydrogen bonds. Then, the existence of intra-molecular hydrogen-bonds was deduced from the spectroscopic data obtained in diluted solution.

The significant ${ }^{1} \mathrm{H}-\mathrm{NMR}$ parameters, which are usually examined in these studies are: a) the amide proton chemical shift $\left(\delta_{\mathrm{NH}}\right)$, b) the change of $\delta_{\mathrm{NH}}$ upon addition of $20 \%$ DMSO, c) the value of the temperature coefficient $\left(\Delta \delta_{\mathrm{NH}} / \Delta \mathrm{T}\right) .{ }^{16-19,40-44}$ Concerning the latter parameter we must outline that it does not always represent a key factor to establish the formation of hydrogen bonds, particularly in the case of cross-linked peptides. ${ }^{45-47}$

It can be helpful to remember that three different states can be distinguished on the basis of the above ${ }^{1} \mathrm{H}-\mathrm{NMR}$ parameters when measured in diluted solution (1-2 $\mathrm{mM}$ in deutero chloroform): i) Amide protons involved in strong hydrogen bonds. This situation can be associated with low temperature coefficient $(\Delta \delta / \Delta \mathrm{T}<2.6 \mathrm{ppb} / \mathrm{T})$, chemical shift values $>7 \mathrm{ppm}$ and small changes in the chemical shift $(\Delta \delta<0.2 \mathrm{ppm})$ upon addition of a competitive solvent such as DMSO. ii) Non hydrogen-bonded amide protons. This can occur with temperature coefficient values $<2.6 \mathrm{ppb} / \mathrm{T}$, chemical shift values $<7 \mathrm{ppm}$ and $\Delta \delta>>0.2 \mathrm{ppm}$ upon addition of a competitive solvent. iii) Amide protons in equilibrium between hydrogen-bonded and non hydrogen-bonded states. In this case large values of temperature coefficient $(\Delta \delta / \Delta \mathrm{T})$ are observed.

Useful information can also be obtained from IR spectra. In diluted solution $(2 \mathrm{mM})$ a broad band in the range 3300-3370 $\mathrm{cm}^{-1}$ indicates the presence of an intra-molecular hydrogen bond, while a sharp band higher than $3400 \mathrm{~cm}^{-1}$ suggests a free amidic NH stretching. ${ }^{23-26}$

(Table 1 here)

The ${ }^{1}$ H-NMR spectra assignments of the amide protons (labelled as $\mathbf{H}^{\mathbf{1}}, \mathbf{H}^{\mathbf{2}}, \mathbf{H}^{\mathbf{3}}, \mathbf{H}^{\mathbf{4}}, \mathbf{H}^{\mathbf{5}}$ and $\mathbf{H}^{\mathbf{6}}$ according to Figure 1) were decided on the basis of the signals multiplicity and by nOe experiments (see Table 1 and Figure 1).

\section{(Figure 1 here)}

The $\mathbf{H}^{\mathbf{1}}$ and $\mathbf{H}^{\mathbf{2}}$ amide protons were assigned through nOe measurements after considering that the $\mathrm{CH}_{2}$ protons in $\beta$ position to the $-\mathrm{CO}-\mathrm{NH}^{1}$ carbonyl group resonate as a multiplet around $1.9 \mathrm{ppm}$, while the $\mathbf{H}^{4}, \mathbf{H}^{\mathbf{5}}$ and $\mathbf{H}^{\mathbf{6}}$ protons assignment was based on the signal of the $\mathrm{CH}_{2}$ protons in $\alpha$ position to the $-\mathrm{CO}-\mathrm{NH}^{4}$ carbonyl, which resonate as two doublettes (one in the range 2.37-2.55 ppm and the other in the range 2.97-3.17 ppm) (see Figure 1 and Table 1). In addition, in all hexapseudopeptides investigated here only the amide proton $\mathbf{H}^{3}$ can resonate as a multiplet. 
The meaningful ${ }^{1} \mathrm{H}-\mathrm{NMR}$ and IR data registered in diluted solution for substrates $\mathbf{1}, \mathbf{2} \mathbf{a}$ and $\mathbf{2} \mathbf{b}$ are collected in Table 2. Their analysis points out some interesting aspects.

(Table 2 here)

We can put forward two different hypothesis concerning $\mathbf{H}^{\mathbf{1}}$ protons: (1) These protons do not form hydrogen bonds because their chemical shifts are $<7 \mathrm{ppm}$ and the signals are characterized by a non negligible high shift (from $0.4 \mathrm{ppm}$ in $\mathbf{2 b}$ to $1.18 \mathrm{ppm}$ in 1) upon addition of 20\% DMSO; (2) Alternatively, an intra-molecular H-bond forms in all substrates. The temperature coefficients (0.1, 0.7 and $2.3 \mathrm{ppb} / \mathrm{T}$ for substrates $\mathbf{1}, \mathbf{2 a}$ and $\mathbf{2 b}$, respectively) are congruent with both hypothesis. Consequently, since the hypothesized hydrogen bond is exposed to the solvent and is probably a rather labile interaction, it can be easily broken when DMSO is added. In this case the low value of chemical shifts could be explained by local screen effects.

Concerning $\mathbf{H}^{2}$ protons, we believe that they are not involved in hydrogen bonds, except in the case of substrate 1 where the high shift upon addition of 20\% DMSO is rather small i.e. $0.22 \mathrm{ppm}$ (in 2a and $\mathbf{2 b}$ these values are much more significant i.e. 0.94 and $1.05 \mathrm{ppm}$ ). We are prone to think that the $\mathbf{H}^{\mathbf{3}}$ protons in $\mathbf{1}$, despite a chemical shift value of $6.69 \mathrm{ppm}$, participates to a hydrogen bond because the $\delta_{\mathrm{NH}}$ values show a small change upon addition of $20 \%$ DMSO and the temperature coefficient is less than $2.6 \mathrm{ppb} / \mathrm{T}$. Furthermore, since the chemical shift values remains almost unchanged upon addition of $20 \%$ DMSO (formation of an internal hydrogen-bond) and the temperature coefficient values are significantly higher than $2.6 \mathrm{ppb} / \mathrm{T}$ (value usually accepted ${ }^{23-26}$ ), it is plausible to hypothesize in all substrates the existence of a dynamic equilibrium between hydrogen bonded and non hydrogen bonded structures for proton $\mathbf{H}^{4}$ (temperature coefficients are 7.7, 6.3 and $5.5 \mathrm{ppb} / \mathrm{T}$ for $\mathbf{1}, \mathbf{2 a}$ and $\mathbf{2 b}$, respectively).

The spectroscopic data reported in Table 2 also indicate that protons $\mathbf{H}^{\mathbf{5}}$ and $\mathbf{H}^{\mathbf{6}}$ in the pseudopeptide 1 form intra-molecular hydrogen bonds.

The spectroscopic information registered for pseudopeptides $\mathbf{2 a}$ and $\mathbf{2 b}$ (see Table 2) suggest that protons $\mathbf{H}^{\mathbf{3}}, \mathbf{H}^{\mathbf{4}}$ and $\mathbf{H}^{\mathbf{5}}$ are involved in hydrogen bonds. In particular, the temperature coefficient values (in the range $3.5-6.3 \mathrm{ppb} /{ }^{\circ} \mathrm{C}$ ) are indicative of the existence of a dynamic equilibrium between a hydrogen-bonded and a non hydrogen-bonded conformation. $\mathbf{H}^{\mathbf{6}}$ protons also are characterized by chemical shift and temperature coefficient values indicating the involvement in intra-molecular hydrogen bonds. It is worth mentioning that after addition of DMSO the amide protons $\mathbf{H}^{\mathbf{6}}$ in $\mathbf{2} \mathbf{a}$ and $\mathbf{H}^{3}, \mathbf{H}^{\mathbf{5}}$ and $\mathbf{H}^{\mathbf{6}}$ in $\mathbf{2 b}$ are characterized by a low shift instead of a high shift as usually found. ${ }^{22-26}$ This already observed behaviour, ${ }^{24}$ could be caused by a local magnetic field change due to a conformational rearrangement of the molecule upon addition of DMSO. ${ }^{21}$ 
The IR spectra of the various hexapseudopeptides are very similar. They show sharp bands in the characteristic region of free $\mathrm{NH}$ amide absorbance (i.e. at $v>3400 \mathrm{~cm}^{-1}$ ) and broad bands in the range $3275-3378 \mathrm{~cm}^{-1}$ indicating the presence of an intra-molecular hydrogen bond.

We are prone to infer that most probably the presence of a methyl group determining a $S$ configuration at the C-2 carbon of the proline ring (see pseudopeptide $\mathbf{1}$ ) increases the propensity to form intra-molecular hydrogen bonds. In fact, in opposition to the evidence found in $\mathbf{2 a}$ and $\mathbf{2 b}$, in $\mathbf{1}$ the amide $\mathbf{H}^{2}$ protons also are involved in stable hydrogen bonds.

Molecular modelling and conformational analysis. A computational strategy based on a two step protocol has been employed to explore the conformational space (phase space) of pseudopeptides $\mathbf{1}$, $\mathbf{2 a}$ and $\mathbf{2 b}$ and obtain structural information to rationalize the spectroscopic data. ${ }^{16,18,21}$ In a first step a high-temperature quenched molecular dynamics (QMD) has been carried out to identify the most populated regions of the phase space. This preliminary investigation provides the starting point for a new molecular dynamics at ambient temperature. This dynamics gives statistical estimates of the hydrogen bond lifetimes and detects the most common hydrogen bond patterns using a cluster analysis of the trajectory. Clusters can be usefully visualized by means of free energy functions which are projected as contour lines onto a two dimension space formed by the PCA1/PCA2 axes (Figure 2). These coordinates are derived from a Principal Component Analysis. ${ }^{48}$

(Figure 2 here)

In the following we briefly describe the method used to build the diagrams of Figure 2. The free energy change associated with the passage between two different states of a system in thermodynamic equilibrium is given by $\Delta \mathrm{G}=-\mathrm{RT} \ln \left(\mathrm{p}_{1} / \mathrm{p}_{2}\right)$. Here $\mathrm{R}$ is the ideal gas constant, $\mathrm{T}$ is the absolute temperature, and $\mathrm{p}_{\mathrm{i}}(\mathrm{i}=1,2)$ is the probability of finding the system in state $\mathrm{i}$. The two dimensional space defined by the PCA1 and PCA2 axis has been divided into a grid and the free energy has been calculated for each bin of the grid on the basis of the previous equation. The whole set of $G$ values has been shifted in such a way that that the lowest value of the free energy surface corresponds to zero. Thus, the reported $\Delta \mathrm{G}$ values represent the transfer free energies with respect to the bin which has been set to zero. To obtain the $p_{i}$ values the trajectory at ambient temperature has been projected onto the PCA1/PCA2 space and $p_{i}$ corresponds to the number of times the trajectory "visits" a given bin. To check the effect of a different grid size on the thermodynamic properties, different grid spacing has been used to construct the same free energy surface. We have found that a more approximate description of the surfaces is obtained using smaller bin sizes since fewer points are available for each bin. However, these surfaces are all very similar: they show the same overall shape and free energy distribution. Finally, we have decided to use a 50-50 grid spacing. 
(Table 3 here)

Representative conformations of the three pseudopeptides, obtained from cluster analysis, are depicted in Figures 3-5. These conformations correspond to the most populated (most stable) structures within different sets of clusters. These sets have been obtained by grouping together the original clusters on the basis of the similarity of the hydrogen bond pattern (Computational procedure). Hydrogen bond lifetimes for each compound are collected in Table 3.

From Figure 2 we can easily recognize that peptide $\mathbf{1}$ is characterized by the most stable structure (only one conformer dominates the PCA1/PCA2 space). The $\mathbf{H}^{3}$-O4 hydrogen bond (lifetime $97.0 \%$ ) is maintained for the entire simulation. This bond (between the carbonyl oxygen of residue $\mathrm{i}$ and the amide hydrogen of residue $i+3$ and forming a typical ten-member ring) keeps up the tridimensional structure of the peptide in a $\beta$-turn (type I) conformation. This conformation shows a unique hydrogen bond pattern where, besides the $\mathbf{H}^{3}$-O4 hydrogen bond (structurally the most important), we can identify the $\mathbf{H}^{\mathbf{5}}$-O4, the $\mathbf{H}^{\mathbf{2}}$-O7, $\mathbf{H}^{\mathbf{6}}$-O5, $\mathbf{H}^{\mathbf{3}}-\mathrm{O} 7, \mathbf{H}^{\mathbf{1}}$-O2 and $\mathbf{H}^{\mathbf{4}}$-O6 hydrogen bonds (corresponding lifetimes reported in Table 3). As a matter of fact an equilibrium between two different conformations $\mathrm{A} 1$ and $\mathrm{A} 2$ can be detected in the diagram of Figure 2, even if the equilibrium is definitely shifted toward A1 (the corresponding population is $91 \%$ ). In A2 the hydrogen pattern is the same as that observed in A1, but the two conformations show a different orientation of one limb of the peptide (molecular region from O4 to $\mathbf{H}^{\mathbf{6}}$ ). (See Figure 3)

(Figure 3 here)

Peptide 2a has a more flexible structure than peptide $\mathbf{1}$, which features a unique tridimensional arrangement maintained by the $\mathbf{H}^{\mathbf{3}}$-O4 hydrogen bond. The conformational space of peptide $\mathbf{2 a}$ can be roughly divided into three regions ( $\mathrm{A}, \mathrm{B}$ and $\mathrm{C}$ ), each region being characterized by different hydrogen bonds leading to rings of different size (7, 10, 12 or 14-member rings). Region $\mathrm{A}$ is the most populated. The main structural feature is a fourteen-member ring due to the $\mathbf{H}^{4}$-O1 hydrogen bond (see Figure 4). Other hydrogen bonds are $\mathbf{H}^{\mathbf{1}}-\mathrm{O} 2, \mathbf{H}^{\mathbf{3}}-\mathrm{O} 6, \mathbf{H}^{\mathbf{5}}-\mathrm{O} 4$ and $\mathbf{H}^{\mathbf{6}}-\mathrm{O} 5$. Region $\mathrm{B}$ is rather wide and can be divided in two sub-areas, B1 and B2. The hydrogen bonds that characterize this region are two: the 12 membered ring hydrogen bond between $\mathbf{H}^{\mathbf{2}}$-O7 and the $\gamma$-turn $\left(\mathbf{H}^{\mathbf{3}}\right.$-O7) forming the typical 7-membered ring hydrogen bond. Other important hydrogen bonds are $\mathbf{H}^{\mathbf{1}}-\mathrm{O} 2$, $\mathbf{H}^{4}$-O6 and $\mathbf{H}^{6}$-O5.The main difference between B1 and B2 is due to a change in the orientation of the terminal part of the peptide (from $\mathbf{H}^{4}$ to $\mathbf{H}^{6}$ ) that causes the formation in B1 of the additional hydrogen bond $\mathbf{H}^{3}$-O6. Region $\mathrm{C}$ is characterized by a $\beta$-turn motif (type II) with a ten-member ring held together by the hydrogen bond $\mathbf{H}^{\mathbf{3}}-\mathrm{O} 4 . \mathbf{H}^{\mathbf{1}}-\mathrm{O} 2$ and $\mathbf{H}^{\mathbf{6}}-\mathrm{O} 5$ are additional hydrogen bonds that 
characterize the $\mathrm{C}$ region. Inspection of Table 3 shows that $\mathbf{H}^{\mathbf{1}}-\mathrm{O} 2$ and $\mathbf{H}^{\mathbf{6}}-\mathrm{O} 5$ are the hydrogen bonds with the highest lifetimes ( $96.1 \%$ and $82.7 \%$, respectively) because they can be detected for the entire set of conformations of the peptide. The lifetimes of the other hydrogen bonds depend on the local conformation assumed by the peptide: for instance, the lifetimes of the $\mathbf{H}^{4}-\mathrm{O} 1$, the $\mathbf{H}^{2}-\mathrm{O} 7$ and $\mathbf{H}^{3}-\mathrm{O} 4$ hydrogen bonds (responsible for different peptide tridimensional structures) are $40.9 \%$, $32.2 \%$ and $20.3 \%$, respectively).

\section{(Figure 4 here)}

Two wide basins (region A and region B) characterize the conformational space of peptide $\mathbf{2} \mathbf{b}$. The structure corresponding to region A is determined by three important hydrogen bonds: $\mathbf{H}^{2}$-O6, $\mathbf{H}^{\mathbf{3}}$-O6 and $\mathbf{H}^{\mathbf{4}}$-O6. Additional hydrogen bonds can be detected: $\mathbf{H}^{\mathbf{1}}$-O2, $\mathbf{H}^{\mathbf{3}}$-O7, $\mathbf{H}^{\mathbf{5}}$-O4 and $\mathbf{H}^{\mathbf{6}}$-O5 The structure that characterizes region B is similar to that found for region B in the case of peptide 12a: the hydrogen bond $\mathbf{H}^{2}-\mathrm{O} 7$ leads to the formation of a twelve-member ring and $\mathbf{H}^{3}-\mathrm{O} 7$ causes the occurrence of a $\gamma$-turn forming the typical seven-member cycle. Other hydrogen bonds are $\mathbf{H}^{1}-\mathrm{O} 2, \mathbf{H}^{3}-\mathrm{O} 7, \mathbf{H}^{4}-\mathrm{O} 7, \mathbf{H}^{4}-\mathrm{O} 6, \mathbf{H}^{\mathbf{5}}$-O4 and $\mathbf{H}^{\mathbf{6}}$-O5. Again, the hydrogen bond which can be detected in both conformations are the most populated (see lifetimes in Table 3).

\section{(Figure 5 here)}

The computational results can help to answer some questions not elucidated by the spectroscopic data. Our conformational analysis supports the hypothesis that in all substrates $\mathbf{H}^{\mathbf{1}}$ is involved in intra-molecular hydrogen bonds and that the temperature coefficients $\left(2.3,0.1\right.$ and $0.7 \mathrm{ppb} /{ }^{\circ} \mathrm{C}$ for $\mathbf{1}$, $\mathbf{2 a}$ and $\mathbf{2 b}$, respectively) are in inverse ratio to the hydrogen bond stability (corresponding lifetimes are $74.8,96.1$ and $83.4 \%$ ). Also, for substrate 1 our computations confirm the stability of the hydrogen bond involving $\mathbf{H}^{\mathbf{2}}$ (lifetime 93.4\%) and $\mathbf{H}^{\mathbf{3}}$. Moreover, our analysis can explain why $\mathbf{H}^{\mathbf{3}}$ shows a small change $(0.1 \mathrm{ppm})$ of $\delta_{\mathrm{NH}}$ value upon addition of $20 \%$ DMSO. Since the hydrogen bond involving $\mathbf{H}^{3}$, which is responsible for the $\beta$-turn conformation, forms in the inner part of the peptide molecule, the added DMSO hardly can break it or significantly affect its strength. Thus, the screening effect due to the molecular environment can also explain the low chemical shift value of $\mathbf{H}^{3}(6.69 \mathrm{ppm})$.

\section{Conclusions}

Spectroscopic investigation using ${ }^{1} \mathrm{H}$ NMR and IR techniques combined with a conformational analysis based on molecular dynamics (MD) and cluster analysis has been demonstrated to be an 
effective tool to elucidate pseudopeptide structures and to analyze the features of intra-molecular hydrogen bonds involving carbonyl oxygens and amide protons. ${ }^{16,18,21}$ The MD analysis, which provides conformer populations and hydrogen bond lifetimes, is in good agreement with the ${ }^{1} \mathrm{H}$ NMR and IR data. The results indicate that the presence of the methyl group leading to configuration $S$ at the C-2 carbon of the proline ring (see hexapseudopeptide1) increases the propensity to give intra-molecular hydrogen bonds. In agreement with this remark, contrary to what found for pseudopeptide $\mathbf{2 a}$ and $\mathbf{2 b}$, in $\mathbf{1}$ the amide proton $\mathbf{H}^{\mathbf{2}}$ is involved in a stable hydrogen bond. Also, the conformational analysis shows that peptide 1 is characterized by the most stable structure i.e. it exists as a single conformation where the $\mathbf{H}^{3}$-O4 hydrogen bond (lifetime 97,0\%) maintains the tridimensional structure of the peptide in a $\beta$-turn conformation. Our analysis shows that the simple substitution of one (C-2)-H of the proline with a methyl, and the consequent configuration $(R$ or $S$ ) of the new stereogenic centre, strongly affects the conformational features of the peptide. As a consequence different reverse turns are generated. In agreement with this observation (i.e. the presence of the methyl group on the proline ring stabilizes the peptide structure), peptide $1(2 S)$ methyl $(S)$-proline derived) exists only in a fixed $\beta$-turn conformation of type I. Peptide 2 a $((S)$ proline derived) can be found in three different conformations and peptide $\mathbf{2 b}((2 R)$-methyl $(S)$ proline derived) has two main conformations and one of this is a $\gamma$-turn.

Thus, this study clearly shows how small changes in a peptide secondary structure can seriously affect its tri-dimensional folding.

In our opinion these results are rather important in designing new peptidomimetic structures (especially in the mimicking of $\gamma$ and $\beta$-turns) capable of exhibiting therapeutic effects. In particular, we have found that that these modified $(S)$-proline units can be a very interesting scaffold to obtain reverse turn formation through intra-molecular hydrogen bonds. Certainly, pseudopeptide $\mathbf{1}$ is the most interesting example between those examined here: it has potential application in the field of peptidomimetic drugs, because represents a novel simulation of a $\beta$-turn where we have reduced as much as possible entropic effects. This pseudopeptide exists in a single stable conformation, but maintains a non negligible structural flexibility. Thus, upon binding a receptor a more significant structural reorganization is possible with respect to a rigid turn simulation where the hydrogen bond forming the ten-member ring is replaced by a covalent bond. This point is rather important since conformationally stable peptidomimetics pay a lower entropy cost upon binding a receptor. 


\section{Acknowledgements}

\section{The authors are grateful to Professor Sergio Sandri for helpful advice and discussions.}

The authors are also grateful to the University of Bologna for financial support ("Ricerca Fondamentale Orientata, ex 60\%) and CINECA computer centre of Bologna for financial support.

\section{References}

$\dagger$ References 16, 17 and 18 are considered to be Part 1, 2 and 3, respectively.

1. G. D. Rose, L. M. Gierasch, J. A. Smith, Adv. Protein Chem. 1985, 37, 1-109.

2. B. L. Sibanda, J. M. Thornton, Nature 1985, 316, 170-174.

3. G. R. Marshall, Curr. Opin. Struct. Biol. 1992, 2, 904-919.

4. S. P. Wood, I. J. Tickle, A. M. Treharne, J. E. Pitts, Y. Mascarenhas, J. Y. Li, J. Husain, S. Cooper, T. L. Blundell, V. J. Hruby, A. Buku, A. J. Fischmann, H. R. Wyssbrod, Science 1986, 232, 633-636.

5. D. A. Langs, G. D. Smith, J. J. Stezowski, R.E. Hughes, Science 1986, 232, 1240-1242.

6. F. Guarnieri, H. Weinstein, J. Am. Chem. Soc. 1996, 118, 5580-5589.

7. G. D. Smith, J. F. Griffin, Science 1978, 199, 1214-1216.

8. K. D. Stigers, M. J. Soth, J. S. Nowick, Curr. Opin. Chem. Biol. 1999, 3, 714-723.

9. K. Burgess, Acc. Chem. Res. 2001, 34, 826-835.

10. S. Hanessian, G. McNaughton-Smith, H.-G. Lombart, W. D. Lubell, Tetrahedron 1997, 53, 12789-12854.

11. T. Kieber-Emmons, R. Murali, M. I. Greene, Curr. Opin. Biotecnol. 1997, 8, 435-441.

12. K. S. Kee, S. D. Jois, Curr. Pharm. Des. 2003, 9, 1209-1224.

13. J. H. Welsh, O. Zerbe, W. von Philipsborn. J. A. Robinson, FEBS, 1992, 297, 216-220.

14. Y. Che, G. R. Marshall, Biopolymers, 2005, 81, 392-406.

15. Y. Che, G. R. Marshall, J. Med. Chem. 2006, 49, 111-124.

16. D. Balducci, A. Bottoni, M. Calvaresi, G. Porzi, S. Sandri, Tetrahderon Asymmetry 2006, 17, 3273-3281.

17. D. Balducci, E. Emer, F. Piccinelli, G. Porzi, M. Recanatini, S. Sandri, Tetrahderon Asymmetry 2005, 16, 3785-3794.

18. D. Balducci, A. Bottoni, M. Calvaresi, G. Porzi, S. Sandri, Tetrahderon Asymmetry 2007, 18, 1448-1456.

19. D. Balducci, A. Grandi, G. Porzi, S. Sandri, Tetrahderon Asymmetry 2005, 16, 1453-1462.

Balducci, D.; Crupi, S.; Galeazzi, R.; Piccinelli, F.; Porzi, G.; Sandri, S. Tetrahedron Asymmetry $\mathbf{2 0 0 5}, 16,1103$ and references therein. 
20. D. Balducci, G. Porzi, S. Sandri, Tetrahderon Asymmetry 2006, 17, 1521-1528.

21. G. M. Almiento, D. Balducci, A. Bottoni, M. Calvaresi, G. Porzi, Tetrahderon Asymmetry 2007, 18, 2695-2711 and references therein.

22. J. Gasteiger, C. Rudolph, J. Sadowski, Tetrahedron Comp. Meth. 1990, 3, 537-547.

23. J. Sadowski, J. Gasteiger, Chem. Rev. 1993, 93, 2567-2581.

24. D. A. Case, T. A. Darden, T. E. Cheatham, III, C. L. Simmerling, J. Wang, R. E. Duke, R. Luo, K. M. Merz, B. Wang, D. A. Pearlman, M. Crowley, S. Brozell, V. Tsui, H. Gohlke, J. Mongan, V. Hornak, G. Cui, P. Beroza, C. Schafmeister, J. W. Caldwell, W. S. Ross, and P. A. Kollman (2004), AMBER 8, University of California, San Francisco.

25. J. Wang, R. M. Wolf, J. W. Caldwell, P. A. Kollman, D. A. Case, J. Comp. Chem. 2004, 25, 1157-1174.

26. A. Jakalian, B. L. Bush, D. B. Jack,C. I. Bayly, J. Comput. Chem. 2000, 21, 132-146.

27. A. Jakalian, B. J. David, C. I. Bayly, J. Comput. Chem. 2002, 23, 1623-1641.

28. J. Wang, W. Wang, P. A. Kollman, D. A. Case, J. Mol. Graphics Modell. 2006, 25, 247-260.

29. G. D. Hawkins, C. J. Cramer, D. G. Truhlar, Chem. Phys. Lett. 1995, 246, 122-129.

30. G. D. Hawkins, C. J. Cramer, D. G. Truhlar, J. Phys. Chem. 1996, 100, 19824-19839.

31. D. Bashford, D. A. Case, Annu. Rev. Phys. Chem. 2000, 51, 129-152.

32. A. K. Felts, E. Gallicchio, A. Wallqvist, R. M. Levy, Proteins: Struct., Funct., Genet. 2002, 48, 404-422.

33. S. Jang, S. Shin, Y. Pak, J. Am. Chem. Soc. 2002, 124, 4976-4977.

34. C. Simmerling, B. Strockbine, A. E. Roitberg, J. Am. Chem. Soc. 2002, 124, 11258-11259.

35. S. Chowdhury, M. C. Lee, G. M. Xiong, Y. Duan, J. Mol. Biol. 2003, 327, 711-717.

36. B. Zagrovic, C. D. Snow, M. R. Shirts,V. S. Pande, J. Mol. Biol. 2002, 323, 927-937.

37. J. P. Ryckaert, G. Ciccotti, H. J. C. Berendsen, J. Comput. Phys. 1977, 23, 327-341.

38. J. Weiser, P. S. Shenkin, W. C. Still, J. Comput. Chem. 1999, 20, 217-230.

39. M. Feig, J. Karanicolas, C. L. Brooks, III: MMTSB Tool Set (2001), MMTSB NIH Research Resource, The Scripps Research Institute.

40. L. Belvisi, A. Bernardi, L. Manzoni, D. Potenza, C. Scolastico, Eur. J. Org. Chem. 2000, 14, 2563-2569.

41. D. Yang; B. Li, F.-F. Ng, Y.-L. Yan, J. Qu, Y.-D. Wu J. Org. Chem. 2001, 66, 7303-7312.

42. M. M. Fernandez, A. Diez, M. Rubiralta, E. Montenegro, N. Casamitjana, M. J. Kogan, E. Giralt, J. Org. Chem. 2002, 67, 7587-7599.

43. A. Trabocchi, E. G. Occhiato, D. Potenza, A. Guarna, J. Org. Chem. 2002, 67, 7483-7492. 
44. B. Bong-hyeon; L. Myung-ryul; K. Kwang-Yon; C. Ung-in; B. Doo Wan; S. Injae Organic Letters 2003, 5, 971-974.

45. N. H. Andersen, J. W. Neidigh, S. M. Harris, G. M. Lee, Z. Liu, H. Tong, J. Am. Chem. Soc. 1997, 119, 8547-8561.

46. N. J. Baxter, M. P. Williamson, J. Biomol. NMR 1997, 9, 359-369.

47. T. Cierpicki, J. Otlewski, J. Biomol. NMR 2001, 21, 249-261.

48. A. Garcia, Phis. Rev. Lett. 1992, 66, 2696-2699. 
Scheme 1. a) $\mathrm{R}=\mathrm{H}$; b) $\mathrm{R}=\mathrm{CH}_{3}$.

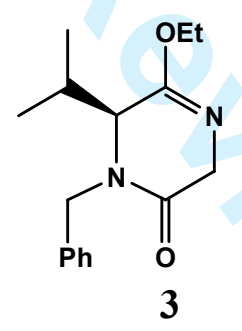

Scheme 2. The chiral synthon used in the synthesis. 


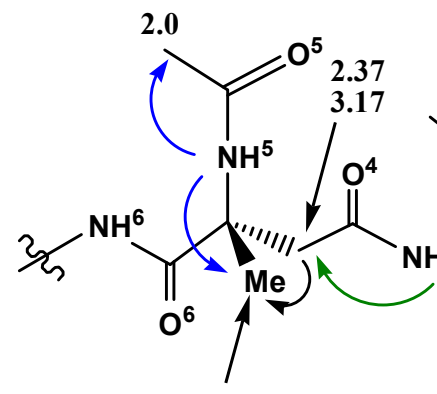

1.6

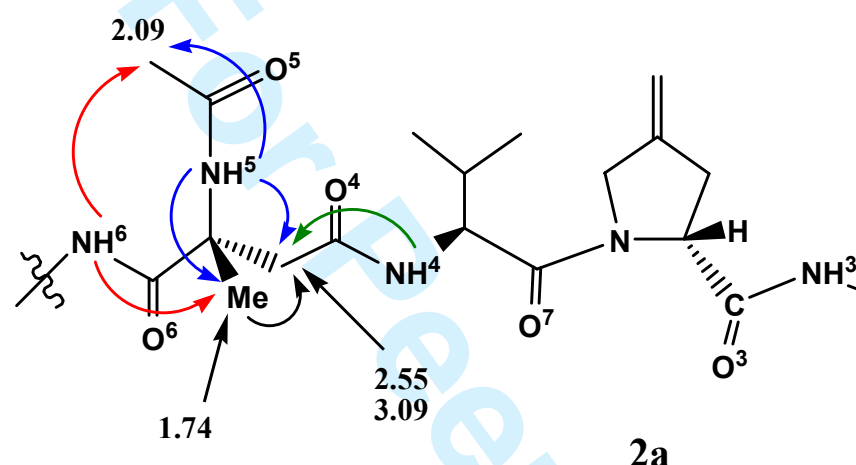

$2 \mathbf{a}$

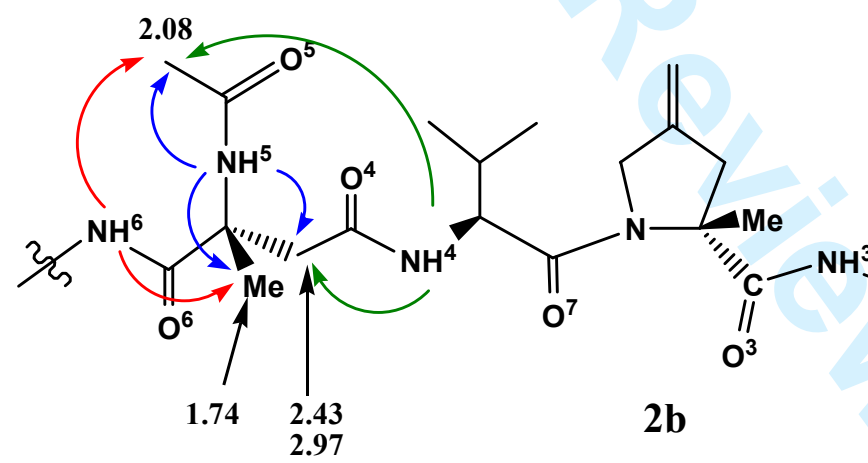

Figure 1. Selected nOe enhancement for substrates 1, 2a, and $\mathbf{2 b}$. 

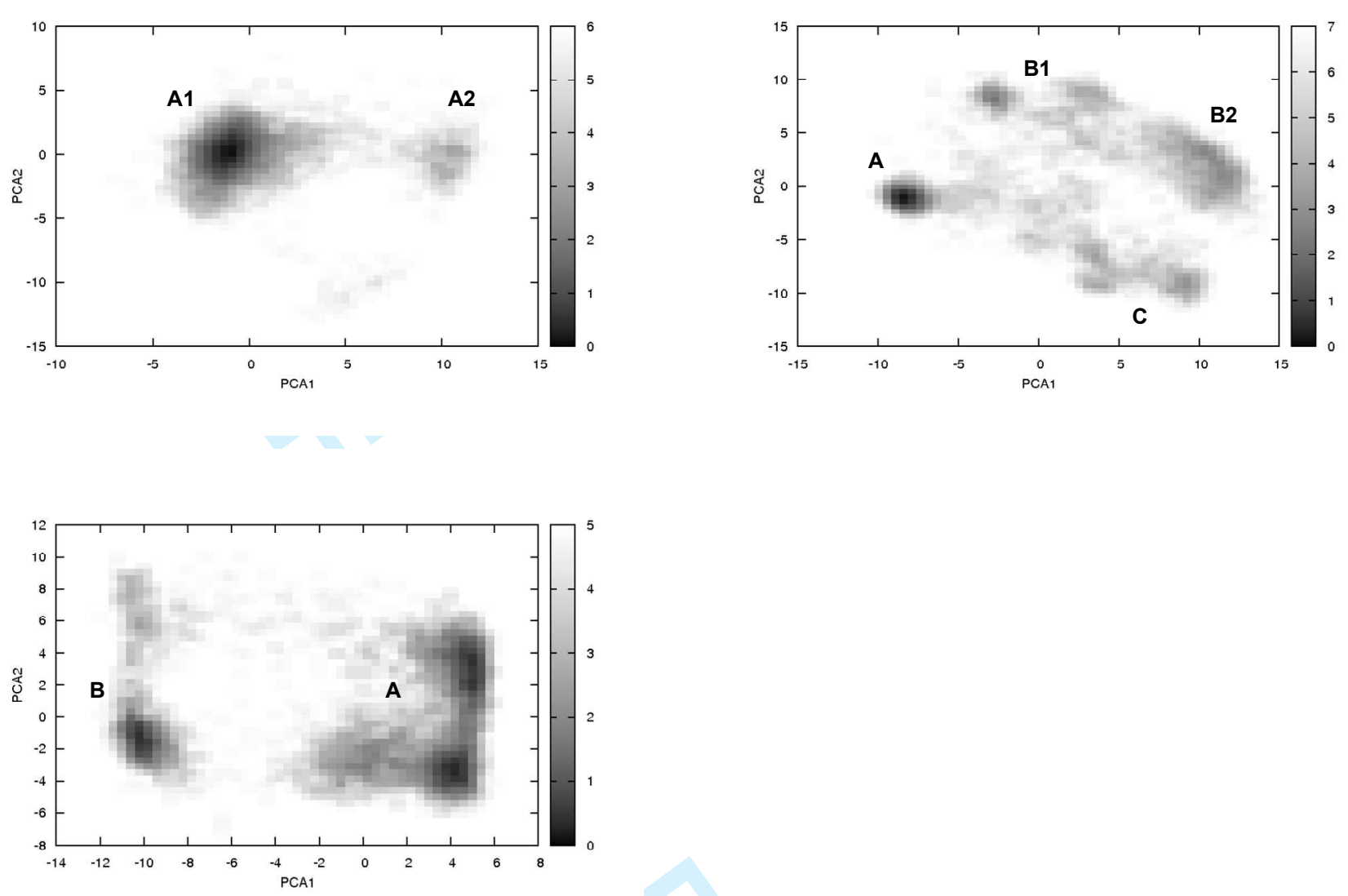

Figure 2. Two dimension free energy profiles for peptides $\mathbf{1}, \mathbf{2 a}$ and $\mathbf{2 b}$ as a function of PCA1 and PCA2. The values on the diagrams are given in $\mathrm{kcal} \mathrm{mol}^{-1}$. 
A1

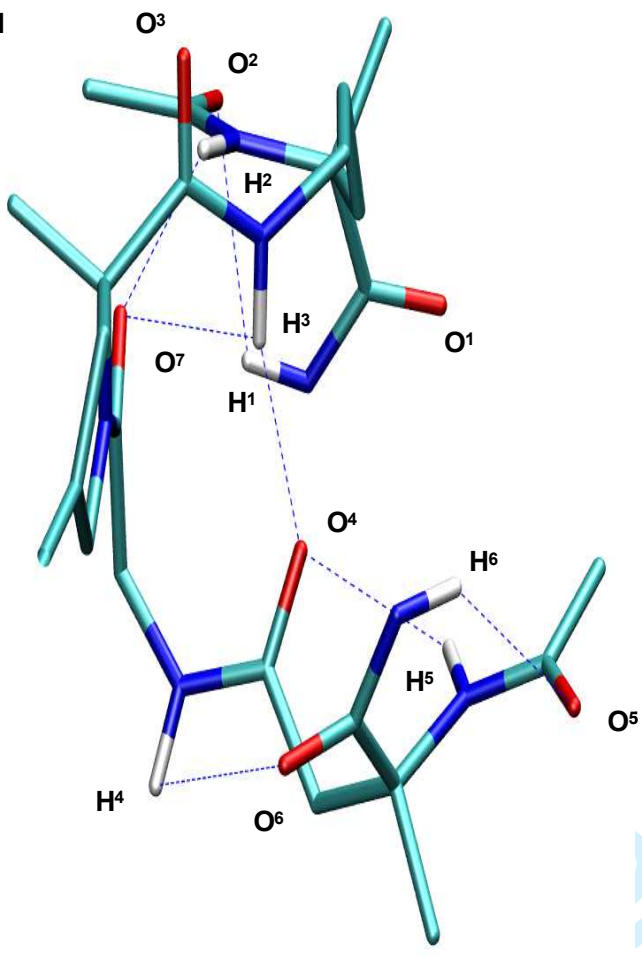

A2
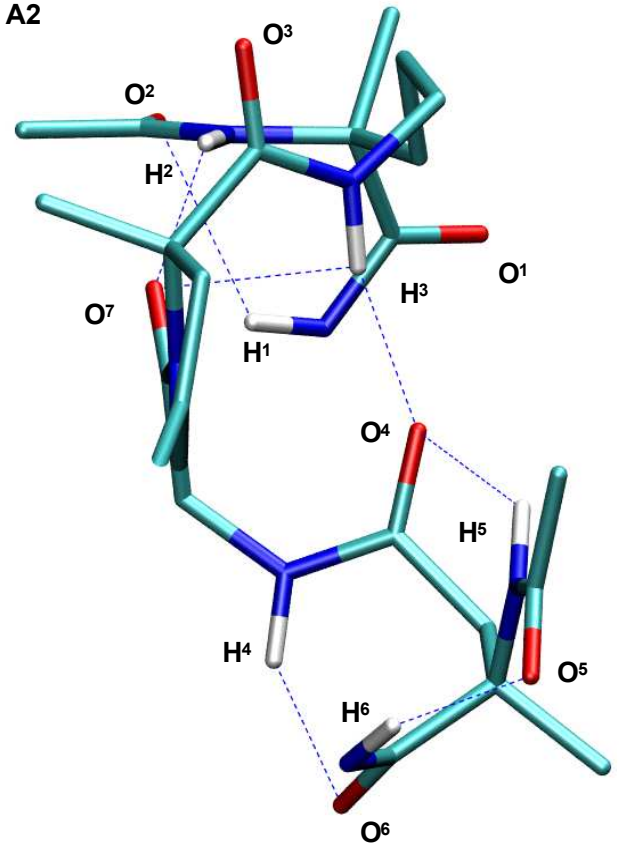

Figure 3. Representative conformations for pseudopeptide 1. 

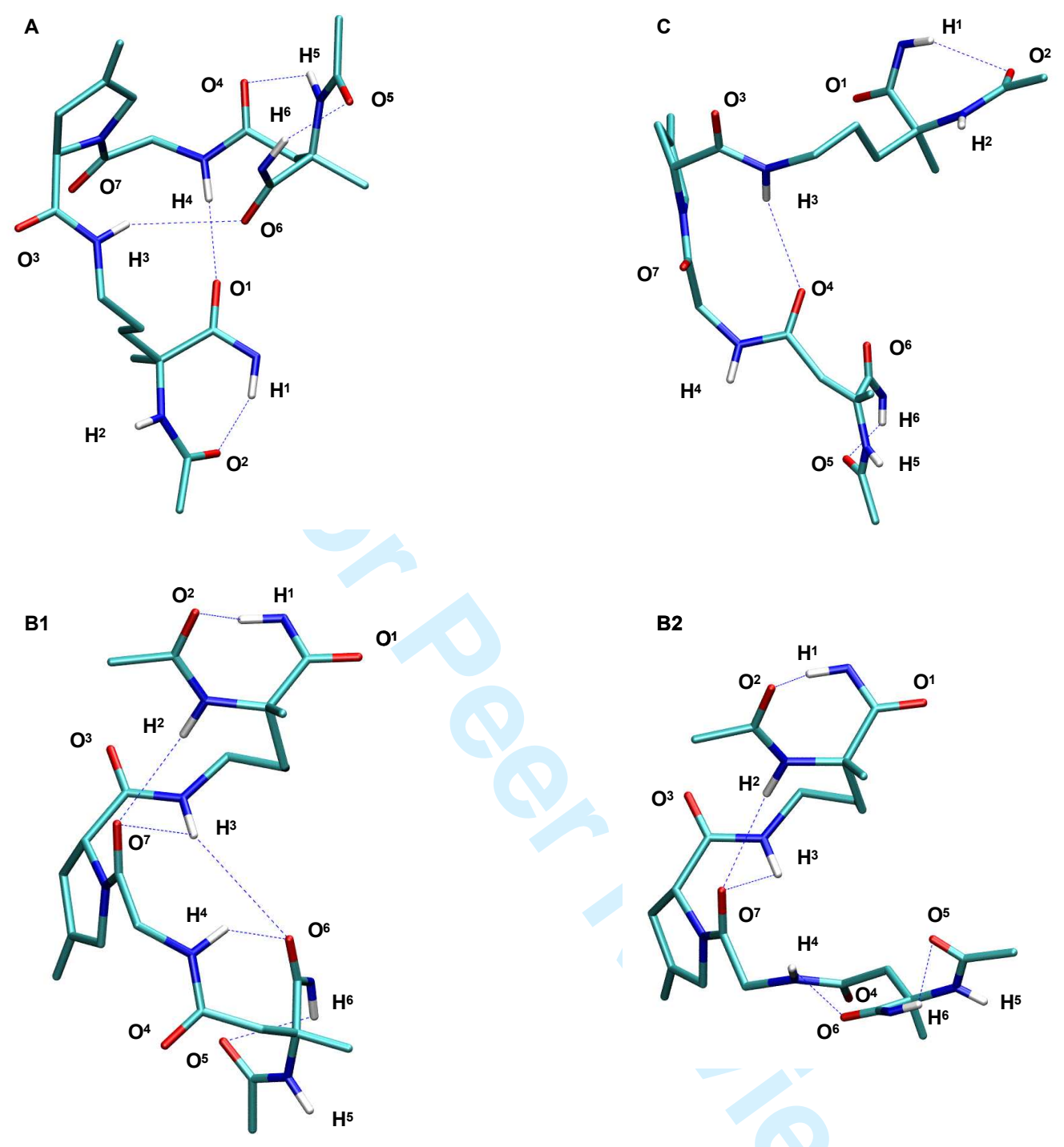

Figure 4. Representative conformations for pseudopeptide 2a 

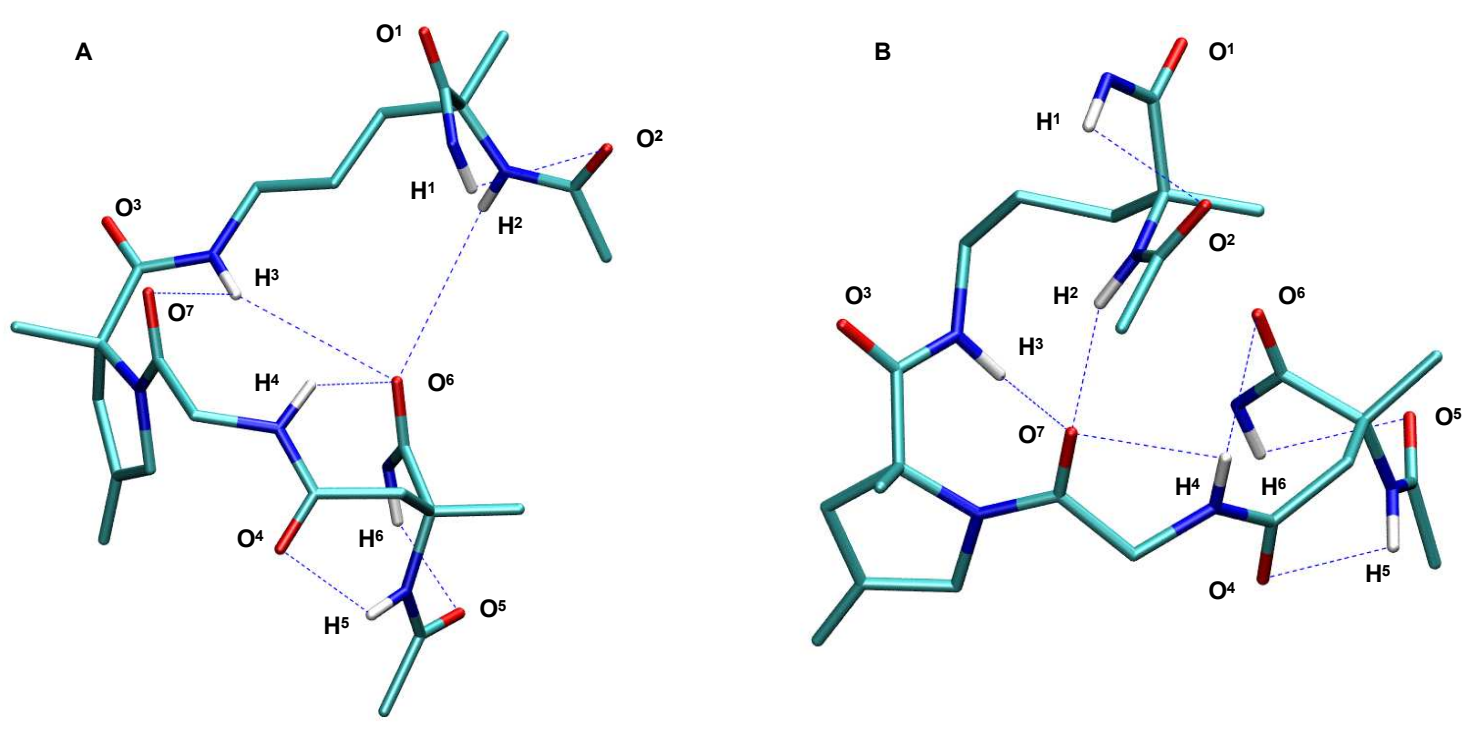

Figure 5. Representative conformations for pseudopeptide $\mathbf{2 b}$. 
Table 1. Selected nOe data for substrates $\mathbf{1}, \mathbf{2 a}$ and $\mathbf{2 b}$.

\begin{tabular}{|c|c|c|}
\hline & Proton irradiated & nOe registered on the proton underlined \\
\hline \multirow{5}{*}{1} & $\mathrm{NH}^{1}(\mathrm{~d})$ at $6.48 \mathrm{ppm}$ & $\begin{array}{c}\mathrm{C}_{\mathrm{H}_{3}}-\mathrm{CO}(\mathrm{s}) \text { at } 1.98 \mathrm{ppm} \\
\mathrm{C}_{3}-\mathrm{CNH}^{2} \text { (s) at } 1.64 \mathrm{ppm}\end{array}$ \\
\hline & $\mathrm{NH}^{2}(\mathrm{~s})$ at $7.05 \mathrm{ppm}$ & $\mathrm{CH}_{3}-\mathrm{CNH}^{2}$ (s) at $1.64 \mathrm{ppm}$ \\
\hline & $\mathrm{NH}^{4}(\mathrm{~d})$ at $7.54 \mathrm{ppm}$ & $\mathrm{CH}_{2}-\mathrm{CNH}^{5}(\mathrm{~d})$ at $3.17 \mathrm{ppm}$ \\
\hline & $\mathrm{NH}^{5}(\mathrm{~s})$ at $7.33 \mathrm{ppm}$ & $\begin{array}{c}\mathrm{C}_{3}-\mathrm{CO}(\mathrm{s}) \text { at } 2.0 \mathrm{ppm} \\
\underline{\mathrm{C}}_{3}-\mathrm{CNH}^{5} \text { (s) at } 1.60 \mathrm{ppm}\end{array}$ \\
\hline & $\mathrm{CH}_{2}-\mathrm{CNH}^{5}(\mathrm{~d})$ at $2.37 \mathrm{ppm}$ & $\mathrm{CH}_{3}-\mathrm{CNH}^{5}(\mathrm{~s})$ at 1.60 \\
\hline \multirow{6}{*}{$\mathbf{2 a}$} & $\mathrm{NH}^{1}(\mathrm{~d})$ at $6.75 \mathrm{ppm}$ & $\begin{array}{c}\mathrm{CH}_{3}-\mathrm{CO}(\mathrm{s}) \text { at } 2.05 \mathrm{ppm} \\
\underline{\mathrm{CH}}_{3}-\mathrm{CNH}^{2}(\mathrm{~s}) \text { at } 1.58 \mathrm{ppm} \\
\underline{\mathrm{CH}}_{2}-\mathrm{CNH}^{2}(\mathrm{~m}) \text { at } 1.87 \mathrm{ppm}\end{array}$ \\
\hline & $\mathrm{CH}_{3}-\mathrm{CNH}^{2}(\mathrm{~s})$ at $1.58 \mathrm{ppm}$ & $\underline{\mathrm{CH}}_{2}-\mathrm{CNH}^{2}(\mathrm{~m})$ at $1.87 \mathrm{ppm}$ \\
\hline & $\mathrm{NH}^{4}(\mathrm{~d})$ at $7.97 \mathrm{ppm}$ & $\mathrm{CH}_{2}-\mathrm{CNH}^{5}(\mathrm{~d})$ at $3.09 \mathrm{ppm}$ \\
\hline & $\mathrm{NH}^{5}(\mathrm{~s})$ at $7.91 \mathrm{ppm}$ & $\begin{array}{c}\underline{\mathrm{CH}}_{2}-\mathrm{CNH}^{5} \text { doublettes at } 2.55 \text { and } 3.09 \mathrm{ppm} \\
\underline{\mathrm{CH}}_{3}-\mathrm{CNH}^{5} \text { (s) at } 1.74 \mathrm{ppm} \\
\underline{\mathrm{CH}}_{3}-\mathrm{CO} \text { (s) at } 2.09 \mathrm{ppm}\end{array}$ \\
\hline & $\mathrm{CH}_{3}-\mathrm{CNH}^{5}$ (s) at $1.74 \mathrm{ppm}$ & $\mathrm{CH}_{2}-\mathrm{CNH}^{5}$ doublettes at 2.55 and $3.09 \mathrm{ppm}$ \\
\hline & $\mathrm{NH}^{6}(\mathrm{~d})$ at $8.14 \mathrm{ppm}$ & $\begin{array}{c}\mathrm{C}_{\mathrm{H}_{3}}-\mathrm{CNH}^{5}(\mathrm{~s}) \text { at } 1.74 \mathrm{ppm} \\
\underline{\mathrm{CH}}_{3}-\mathrm{CO} \text { (s) at } 2.09 \mathrm{ppm}\end{array}$ \\
\hline \multirow{6}{*}{$\mathbf{2 b}$} & $\mathrm{NH}^{1}(\mathrm{~d})$ at $6.80 \mathrm{ppm}$ & $\begin{array}{c}\mathrm{CH}_{2}-\mathrm{CNH}^{2}(\mathrm{~m}) \text { at } 1.9 \mathrm{ppm} \\
\mathrm{CH}_{3}-\mathrm{CO}(\mathrm{s}) \text { at } 2.03 \mathrm{ppm} \\
\underline{\mathrm{CH}}_{3}-\mathrm{CNH}^{2} \text { (s) at } 1.57 \mathrm{ppm}\end{array}$ \\
\hline & $\mathrm{CH}_{3}-\mathrm{CNH}^{2}(\mathrm{~s})$ at $1.57 \mathrm{ppm}$ & $\mathrm{CH}_{2}-\mathrm{CNH}^{2}(\mathrm{~m})$ at $1.9 \mathrm{ppm}$ \\
\hline & $\mathrm{NH}^{2}(\mathrm{~s})$ at $6.40 \mathrm{ppm}$ & $\begin{array}{c}\mathrm{CH}_{3}-\mathrm{CO}(\mathrm{s}) \text { at } 2.03 \mathrm{ppm} \\
\mathrm{C}_{3}-\mathrm{CNH}^{2} \text { (s) at } 1.57 \mathrm{ppm}\end{array}$ \\
\hline & $\mathrm{NH}^{4}(\mathrm{~d})$ at $8.09 \mathrm{ppm}$ & $\begin{array}{l}\mathrm{CH}_{2}-\mathrm{NH}^{5}(\mathrm{~d}) \text { at } 2.97 \mathrm{ppm} \\
\underline{\mathrm{CH}}_{3}-\mathrm{CO}(\mathrm{s}) \text { at } 2.08 \mathrm{ppm}\end{array}$ \\
\hline & $\mathrm{NH}^{5}(\mathrm{~s})$ at $8.22 \mathrm{ppm}$ & $\begin{array}{c}\mathrm{CH}_{2}-\mathrm{CNH}^{5} \text { doublettes at } 2.43 \text { and } 2.97 \mathrm{ppm} \\
\mathrm{C}_{3}-\mathrm{CO}(\mathrm{s}) \text { at } 2.08 \mathrm{ppm} \\
\underline{\mathrm{CH}}_{3}-\mathrm{CNH}^{5} \text { (s) at } 1.74 \mathrm{ppm}\end{array}$ \\
\hline & $\mathrm{NH}^{6}(\mathrm{~d})$ at $8.31 \mathrm{ppm}$ & $\begin{array}{c}\mathrm{C}_{\mathrm{H}_{3}}-\mathrm{CNH}^{5}(\mathrm{~s}) \text { at } 1.74 \mathrm{ppm} \\
\mathrm{C}_{3}-\mathrm{CO}(\mathrm{s}) \text { at } 2.08 \mathrm{ppm}\end{array}$ \\
\hline
\end{tabular}


Table 2. Meaningful ${ }^{1} \mathrm{H}-\mathrm{NMR}$ and IR data of substrates $\mathbf{1 , 2} \mathbf{2}$ and $\mathbf{2 b}$

\begin{tabular}{|c|c|c|c|c|}
\hline & $\boldsymbol{\delta}_{\mathrm{NH}}(\mathrm{ppm})(\mathrm{a})$ & $\boldsymbol{\delta}_{\mathrm{NH}}(\mathrm{ppm})(\mathrm{b})$ & \begin{tabular}{|l|l}
$\Delta \boldsymbol{\delta}_{\mathrm{NH}} / \Delta \mathrm{T}$ & $\left(\mathrm{ppb} /{ }^{\circ} \mathrm{C}\right)(\mathrm{a})$
\end{tabular} & $\operatorname{IR}\left(\mathrm{cm}^{-1}\right)(\mathrm{c})$ \\
\hline 1 & $\begin{array}{ll}\mathbf{H}^{\mathbf{1}} & 6.48(\mathrm{~d}) \\
\mathbf{H}^{2} & 7.05(\mathrm{~s}) \\
\mathbf{H}^{3} & 6.69(\mathrm{~m}) \\
\mathbf{H}^{4} & 7.54(\mathrm{~d}) \\
\mathbf{H}^{\mathbf{5}} & 7.33(\mathrm{~s}) \\
\mathbf{H}^{\mathbf{6}} & 7.94(\mathrm{~d}) \\
\end{array}$ & $\begin{array}{ll}\mathbf{H}^{\mathbf{1}} & 7.66 \\
\mathbf{H}^{2} & 7.27 \\
\mathbf{H}^{\mathbf{3}} & 6.79 \\
\mathbf{H}^{\mathbf{4}} & 7.55 \\
\mathbf{H}^{\mathbf{5}} & 7.72 \\
\mathbf{H}^{\mathbf{6}} & 7.72 \\
\end{array}$ & $\begin{array}{ll}\mathbf{H}^{\mathbf{1}} & 2.3 \\
\mathbf{H}^{\mathbf{2}} & 4.4 \\
\mathbf{H}^{\mathbf{3}} & 2.1 \\
\mathbf{H}^{\mathbf{4}} & 7.7 \\
\mathbf{H}^{\mathbf{5}} & 0.7 \\
\mathbf{H}^{\mathbf{6}} & 1.0 \\
\end{array}$ & $3429 ; 3375 ; 3285$ \\
\hline $2 \mathbf{a}$ & $\begin{array}{ll}\mathbf{H}^{\mathbf{1}} & 6.75(\mathrm{~d}) \\
\mathbf{H}^{2} & 6.56(\mathrm{~s}) \\
\mathbf{H}^{3} & 7.15(\mathrm{~m}) \\
\mathbf{H}^{4} & 7.97(\mathrm{~d}) \\
\mathbf{H}^{5} & 7.91(\mathrm{~s}) \\
\mathbf{H}^{\mathbf{6}} & 8.14(\mathrm{~d}) \\
\end{array}$ & $\begin{array}{ll}\mathbf{H}^{\mathbf{1}} & 7.29 \\
\mathbf{H}^{\mathbf{2}} & 7.50 \\
\mathbf{H}^{\mathbf{3}} & 7.25 \\
\mathbf{H}^{\mathbf{4}} & 8.02 \\
\mathbf{H}^{\mathbf{5}} & 7.93 \\
\mathbf{H}^{\mathbf{6}} & 7.74 \\
\end{array}$ & $\begin{array}{ll}\mathbf{H}^{\mathbf{1}} & 0.1 \\
\mathbf{H}^{\mathbf{2}} & 1.1 \\
\mathbf{H}^{\mathbf{3}} & 3.5 \\
\mathbf{H}^{\mathbf{4}} & 6.3 \\
\mathbf{H}^{\mathbf{5}} & 5.1 \\
\mathbf{H}^{\mathbf{6}} & 2.8 \\
\end{array}$ & $3428 ; 3378 ; 3275$ \\
\hline $2 \mathbf{b}$ & $\begin{array}{ll}\mathbf{H}^{1} & 6.80(\mathrm{~d}) \\
\mathbf{H}^{2} & 6.40(\mathrm{~s}) \\
\mathbf{H}^{3} & 7.21(\mathrm{~m}) \\
\mathbf{H}^{4} & 8.09(\mathrm{~d}) \\
\mathbf{H}^{5} & 8.22(\mathrm{~s}) \\
\mathbf{H}^{6} & 8.31(\mathrm{~d})\end{array}$ & $\begin{array}{ll}\mathbf{H}^{\mathbf{1}} & 7.20 \\
\mathbf{H}^{\mathbf{2}} & 7.45 \\
\mathbf{H}^{\mathbf{3}} & 7.11 \\
\mathbf{H}^{\mathbf{4}} & 8.20 \\
\mathbf{H}^{\mathbf{5}} & 8.07 \\
\mathbf{H}^{\mathbf{6}} & 7.94\end{array}$ & $\begin{array}{ll}\mathbf{H}^{\mathbf{1}} & 0.7 \\
\mathbf{H}^{2} & 0.1 \\
\mathbf{H}^{3} & 3.6 \\
\mathbf{H}^{4} & 5.5 \\
\mathbf{H}^{\mathbf{5}} & 4.9 \\
\mathbf{H}^{6} & 2.5\end{array}$ & $3431 ; 3373 ; 3288$ \\
\hline
\end{tabular}

(a) $2 \mathrm{mM}$ solution in $\mathrm{CDCl}_{3}$; (b) $2 \mathrm{mM}$ solution in $\mathrm{CDCl}_{3}+20 \% \mathrm{DMSO}$; (c) $2 \mathrm{mM}$ solution in $\mathrm{CHCl}_{3}$. 
Table 3. Lifetimes for the various hydrogen bonds in substrates $\mathbf{1}, \mathbf{2 a}$ and $\mathbf{2 b}$

\begin{tabular}{|c|c|c|}
\hline Substrates & Hydrogen bond & Lifetime (\%) \\
\hline \multirow[t]{7}{*}{1} & $\mathbf{H}^{\mathbf{3}}-\mathrm{O} 4$ & 97.0 \\
\hline & $\mathbf{H}^{5}-\mathrm{O} 4$ & 93.6 \\
\hline & $\mathbf{H}^{2}-\mathrm{O} 7$ & 93.4 \\
\hline & $\mathbf{H}^{6}-\mathrm{O} 5$ & 93.1 \\
\hline & $\mathbf{H}^{\mathbf{3}}-\mathrm{O} 7$ & 78.6 \\
\hline & $\mathbf{H}^{\mathbf{1}}-\mathrm{O} 2$ & 74.8 \\
\hline & $\mathbf{H}^{4}-\mathrm{O} 6$ & 19.6 \\
\hline \multirow[t]{9}{*}{$2 \mathbf{a}$} & $\mathbf{H}^{1}-\mathrm{O} 2$ & 96.1 \\
\hline & $\mathbf{H}^{\mathbf{6}}-\mathrm{O} 5$ & 82.7 \\
\hline & $\mathbf{H}^{\mathbf{3}}-\mathrm{O} 7$ & 77.8 \\
\hline & $\mathbf{H}^{4}-\mathrm{O} 6$ & 71.7 \\
\hline & $\mathbf{H}^{\mathbf{5}}-\mathrm{O} 4$ & 42.1 \\
\hline & $\mathbf{H}^{4}-\mathrm{O} 1$ & 40.9 \\
\hline & $\mathbf{H}^{3}-\mathrm{O} 6$ & 35.2 \\
\hline & $\mathbf{H}^{2}-\mathrm{O} 7$ & 32.2 \\
\hline & $\mathbf{H}^{3}-\mathrm{O} 4$ & 20.3 \\
\hline \multirow[t]{10}{*}{$2 \mathbf{b}$} & $\mathbf{H}^{\mathbf{5}}-\mathrm{O} 4$ & 93.7 \\
\hline & $\mathbf{H}^{6}-\mathrm{O} 5$ & 88.6 \\
\hline & $\mathbf{H}^{\mathbf{1}}-\mathrm{O} 2$ & 83.4 \\
\hline & $\mathbf{H}^{\mathbf{3}}-\mathrm{O} 7$ & 81.6 \\
\hline & $\mathbf{H}^{4}-\mathrm{O} 6$ & 65.7 \\
\hline & $\mathbf{H}^{4}-\mathrm{O} 7$ & 51.1 \\
\hline & $\mathbf{H}^{2}-\mathrm{O} 6$ & 44.9 \\
\hline & $\mathbf{H}^{\mathbf{6}}-\mathrm{O} 4$ & 35.8 \\
\hline & $\mathbf{H}^{3}-\mathrm{O} 6$ & 22.4 \\
\hline & $\mathbf{H}^{2}-\mathrm{O} 7$ & 21.8 \\
\hline
\end{tabular}


Supplementary material for the paper

\title{
Conformational Analysis \\ of Hexapseudopeptides Mimicking Reverse Turn Structures Induced by a Modified (S)-Proline. A Combined Spectroscopic and Molecular Dynamics Investigation. Part $4 \dagger$
}

\author{
Daniele Balducci,* Andrea Bottoni, Matteo Calvaresi,* Gianni Porzi \\ Dipartimento di Chimica “G.Ciamician”, Università di Bologna, Via Selmi 2, 40126 Bologna, Italy. \\ e-mail : andrea.bottoni@unibo.it
}

\section{Synthesis}

The synthesis of the unnatural hexapeptide 1 was carried out using the masked cyclic dipeptides $\mathbf{4}^{20}, \mathbf{5}^{19}$ and $\mathbf{7}$, which were synthesized starting from the chiral synthon $\mathbf{3}$. ${ }^{19}$ The masked dipeptide $\mathbf{5}$ was coupled through the free amine group to the cyclic pseudodipeptide 4 , activated as pentafluorophenol ester, to obtain intermediate 6, after alkaline hydrolysis (as previously described $^{16}$ ). The masked hexapseudopeptide $\mathbf{8}$ was then obtained from the reaction of intermediate 6 with the nucleohphile 7 in the presence of 4-(4,6-dimethoxy-1,3,5-triazin-2-yl)-4-methyl morpholinium chloride (DMTMM) (Scheme 1S).

We achieved the cyclic pseudodipeptide 7 through the hydrogenolysis of derivative $9,{ }^{21}$ which was obtained starting from the chiral synthon 3 (Scheme 2S). Intermediate 8 was submitted to acid hydrolysis in mild conditions. Then, we made the diamino derivative (not isolated) to react with acetyl chloride to afford the pseudo hexapeptide 1 containing two L-valine units, (2R)-methyl aspartic acid, $(2 S)$-methylornitine and a modified $(S)$-proline (Scheme 1).

Unnatural hexapeptides $\mathbf{2 a}$ and $\mathbf{2 b}$ were obtained by employing the cyclic pseudodipeptides $\mathbf{1 0 a}$ and $\mathbf{1 0 b}$, respectively (the latter is a diastereomer with respect to 5) and following the same procedure used to synthesize 1 (Scheme $3 \mathrm{~S}$ ). 
<smiles>CCOC1=NCC(=O)N(Cc2ccccc2)[C@H]1C(C)C</smiles>

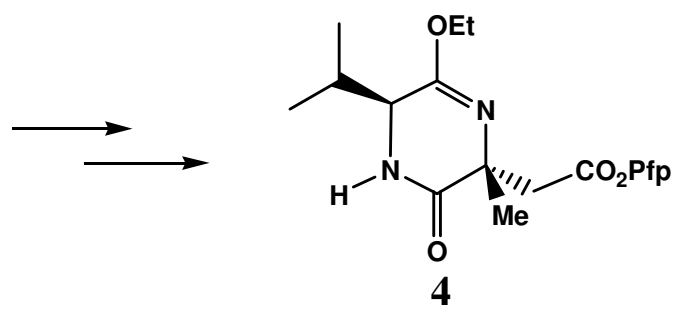<smiles>C=C1CN2C(=O)[C@H](NO)C(C)C[C@]2([C@H](O)CC)C1</smiles><smiles>C=C1CN(C(=O)[C@H](NC(=O)C[C@]2(C)N=C(OCC)[C@@H](C(C)C)NC2=O)C(C)C)[C@](C)(C(=O)O)C1</smiles><smiles>CCOC1=N[C@](C)(CCCN)C(=O)N[C@@H]1C(C)C</smiles><smiles>C#CC</smiles>

6<smiles>C=C1CN(C(=O)[C@@H](NC(=O)CC(C)C)C(C)C)[C@](C)(C(=O)NCCC[C@]2(N)N=C(OCC)[C@@H](C(C)C)NC2=O)C1</smiles><smiles>C=C1CN(C(=O)[C@@H](NC(=O)C[C@@](C)(NC(C)(C)C)C(=O)N[C@H](C(=O)OCC)C(C)C)C(C)C)[C@@](C)(C(N)=O)C1</smiles>

1

Scheme 1S. i) $\mathrm{DMF} / \mathrm{Py}, 24 \mathrm{hr}$ at r.t.; ii) $\mathrm{EtOH} / \mathrm{NaOH}, 70 \mathrm{hr}$ at r.t.; iii) $\mathrm{THF}$, DMTMM at r.t. for 24 hr.; iv) EtOH, 0.5N HCl, $24 \mathrm{hr}$ at r.t., then $\mathrm{CH}_{3} \mathrm{COCl} / \mathrm{Et}_{3} \mathrm{~N}$ in $\mathrm{CH}_{2} \mathrm{Cl}_{2}$.<smiles>CCOC1=NCC(C)C(C(C)C)N1Cc1ccccc1</smiles>
3<smiles>CCOC1=N[C@H](CCCN(Cc2ccccc2)Cc2ccccc2)C(=O)N[C@@H]1C(C)C</smiles>

9<smiles>CCOC1=N[C@](C)(CCCN)C(=O)N[C@@H]1C(C)C</smiles>

7

Scheme 2S. i) $\mathrm{H}_{2} / \mathrm{Pd}(\mathrm{OH})_{2}$ in $\mathrm{MeOH}$. 
<smiles>C=C1CN2C(=O)C(=C)CN(C(=O)[C@@H](NC=CC)C(C)C)[C@]2(C(=O)OCC)C1</smiles>

$10(a, b)$

11(a,b)<smiles>C=C1C[C@@](P)(C(=O)NCCC[C@]2(N)N=C(OCC)[C@@H](C(C)C)NC2=O)N(C(=O)[C@@H](NC(=O)C[C@H]2N=C(OCC)[C@@H](C(C)C)NC2=O)C(C)C)C1=O</smiles>

12(a,b)

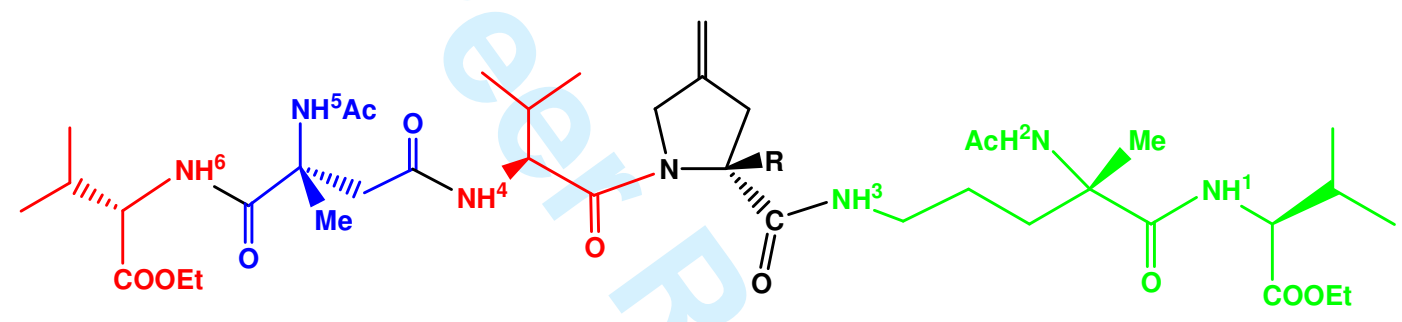

2(a,b)

a) $\mathrm{R}=\mathrm{H}$; b) $\mathrm{R}=\mathrm{CH}_{3}$

Scheme 3S. i) DMF/Py, $24 \mathrm{hr}$ at r.t.; ii) $\mathrm{EtOH} / \mathrm{NaOH}, 70 \mathrm{hr}$ at r.t.; iii) $\mathrm{THF}$, DMTMM at r.t. for 24 hr; iv) $\mathrm{EtOH}, 0.5 \mathrm{~N} \mathrm{HCl}, 24 \mathrm{hr}$ at r.t., then $\mathrm{CH}_{3} \mathrm{COCl} / \mathrm{Et}_{3} \mathrm{~N}$ in $\mathrm{CH}_{2} \mathrm{Cl}_{2}$.

\section{General information}

\subsection{1-[(6-ethoxy-(5S)-isopropyl-(2R)-methyl-2,3,4,5-tetrahydro-3-oxo-pyrazin-2-yl)-(2S)-} isopropyl-3-aza-4-oxo-pentanoyl]-(2S)-[6-ethoxy-(5S)-isopropyl-(2R)-methyl-2,3,4,5tetrahydro-3-oxo-pyrazin-2-yl)-4-aza-5-oxo-pentanoyl]-2-methyl-4-methylenepyrrolidine. (8) The (2S,5S)-2-(3-aminopropyl)-6-ethoxy-5-isopropyl-2-methyl-2,3,4,5-tetrahydropyrazin-3-one (7) $(0.56 \mathrm{~g}, 2.2 \mathrm{mmol})$ dissolved in dry THF $(5 \mathrm{~mL})$ was added to a stirred solution of 6 (0.96 g, 2 $\mathrm{mmol}$ ) in $15 \mathrm{~mL}$ of dry THF. After 10-15 minutes 4-(4,6-dimethoxy-1,3,5-triazin-2-yl)-4-methyl morpholinium chloride (DMTMM) $(0.69 \mathrm{~g}, 2.5 \mathrm{mmol})$ was added and the reaction mixture stirred at r.t. After about $24 \mathrm{hr}$, the solution was diluted with ethyl acetate, the solid phase was filtered off and the organic solution washed with $1 \mathrm{M} \mathrm{HCl}$. The organic solution was dried over $\mathrm{Na}_{2} \mathrm{SO}_{4}$ and 
2.2. (2S,2'S,6'R,9'S,6''S,9''S)-1-(6'-acetamido-3,8-diaza-10-carboxyethyl-2',9'-diisopropyl-4,7dioxo-6'-methyl-decan-1-yl)-2-(6"'-acetamido-2,8-diaza-10-carboxyethyl-9"'-isopropyl-7-oxo6"-methyl-decan-1-yl)-2-methyl-4-methylenepyrrolidine. (5)

$0.5 \mathrm{M} \mathrm{HCl}(8 \mathrm{~mL})$ was added to a solution of $\mathbf{8}(1.43 \mathrm{~g}, 2 \mathrm{mmol})$ dissolved in ethanol $(12 \mathrm{~mL})$ and the reaction mixture was stirred at room temperature, for about $12 \mathrm{hr}$. Then the ethanol was evaporated in vacuo, the residue extracted with $\mathrm{CH}_{2} \mathrm{Cl}_{2}$ and the organic solution dried over $\mathrm{CaCl}_{2}$. After filtration, triethylamine $(0.84 \mathrm{~mL}, 6 \mathrm{mmol})$ was added to the organic solution cooled to $-10^{\circ} \mathrm{C}$ and then acetyl chloride $(0.45 \mathrm{~mL}, 6.3 \mathrm{mmol})$ was dropped under stirring. After about 15 minutes the cooling bath was removed and the reaction mixture was stirred for 2-3 hrs. The organic solvent was then evaporated under vacuum and the residue dissolved in ethyl acetate. The organic solution was washed with $2 \mathrm{M} \mathrm{HCl}$ and then dried over $\mathrm{Na}_{2} \mathrm{SO}_{4}$. After evaporation in vacuo to dryness, the residue was submitted to purification by silica gel chromatography eluting with hexane/ethyl acetate. The pure product was obtained as a wax in $73 \%$ overall yield.

${ }^{1} \mathrm{H}-\mathrm{NMR} \delta$ : $1.0(\mathrm{~m}, 18 \mathrm{H}) ; 1.25(\mathrm{~m}, 6 \mathrm{H}) ; 1.48(\mathrm{~s}, 3 \mathrm{H}) ; 1.60(\mathrm{~s}, 3 \mathrm{H}) ; 1.64(\mathrm{~s}, 3 \mathrm{H}) ; 1.4-2.15(\mathrm{~m}, 4 \mathrm{H}) ; 1.98$ $(\mathrm{s}, 3 \mathrm{H}) ; 2.0(\mathrm{~s}, 3 \mathrm{H}) ; 2.22(\mathrm{~m}, 2 \mathrm{H}) ; 2.37(\mathrm{~d}, 1 \mathrm{H}, \mathrm{J}=15.3) ; 2.55(\mathrm{~m}, 1 \mathrm{H}) ; 2.89\left(\mathrm{q}_{\mathrm{AB}}, 2 \mathrm{H}, \mathrm{J}=14.7\right) ; 3.04(\mathrm{~m}$, 1H); $3.17(\mathrm{~d}, 1 \mathrm{H}, \mathrm{J}=15.3) ; 3.63(\mathrm{~m}, 1 \mathrm{H}) ; 4.2(\mathrm{~m}, 5 \mathrm{H}) ; 4.45(\mathrm{~m}, 4 \mathrm{H}) ; 5.07(\mathrm{~m}, 2 \mathrm{H}) ; 6.48(\mathrm{~d}, 1 \mathrm{H}, \mathrm{J}=9) ; 6.69$ $(\mathrm{m}, 1 \mathrm{H}) ; 7.05(\mathrm{~s}, 1 \mathrm{H}) ; 7.33 .(\mathrm{s}, 1 \mathrm{H}) ; 7.54(\mathrm{~d}, 1 \mathrm{H}, \mathrm{J}=8) ; 7.94(\mathrm{~d}, 1 \mathrm{H}, \mathrm{J}=8.2) .{ }^{13} \mathrm{C}-\mathrm{NMR} \delta: 14.01,17.4$, 18.0, 18.6, 19.0, 19.1, 19.2, 20.1, 22.7, 23.9, 24.0, 24.1, 30.2, 30.9, 33.8, 42.3, 45.7, 52.8, 56.5, 57.6, 58.2, 58.8, 60.6, 61.0, 61.2, 67.4, 100.5, 141.8, 169.4, 169.9, 170.5, 170.7, 171.6, 172.7, 172.9, 173.5, 175.1. $[\alpha]_{D} 18.6$ (c 1.1, $\mathrm{CHCl}_{3}$ ). Anal. Calcd. for $\mathrm{C}_{41} \mathrm{H}_{69} \mathrm{~N}_{7} \mathrm{O}_{11}$ : C,58.59; $\mathrm{H}, 8.32 ; \mathrm{N}, 11.73$. Found: C,58.5; H,8.35; N,11.68. 


\subsection{1-[(6-ethoxy-(5S)-isopropyl-(2R)-methyl-2,3,4,5-tetrahydro-3-oxo-pyrazin-2-yl)-(2S)-} isopropyl-3-aza-4-oxo-pentanoyl]-(2R)-[6-ethoxy-(5S)-isopropyl-(2R)-methyl-2,3,4,5tetrahydro-3-oxo-pyrazin-2-yl)-4-aza-5-oxo-pentanoyl]-4-methylenepyrrolidine. (12a) It was obtained by reacting 10a with 7 in the presence of DMTMM and following the procedure described for $\mathbf{8}$. The crude reaction product was submitted to silica gel chromatography eluting with hexane/ethyl acetate and the product was recovered as an oil in $72 \%$ yield.

${ }^{1} \mathrm{H}-\mathrm{NMR} \delta$ : 0.85 (d,3H,J=6.9); $0.90(\mathrm{~d}, 3 \mathrm{H}, \mathrm{J}=6.9) ; 1.0(\mathrm{~m}, 12 \mathrm{H}) ; 1.28(\mathrm{t}, 3 \mathrm{H}, \mathrm{J}=7.2) ; 1.29(\mathrm{t}, 3 \mathrm{H}, \mathrm{J}=7.2)$; $1.37(\mathrm{~s}, 3 \mathrm{H}) ; 1.47(\mathrm{~s}, 3 \mathrm{H}) ; 1.60(\mathrm{~m}, 2 \mathrm{H}) ; 2.0(\mathrm{~m}, 2 \mathrm{H}) ; 2.28(\mathrm{~m}, 3 \mathrm{H}) ; 2.36(\mathrm{~d}, 1 \mathrm{H}, \mathrm{J}=14.4) ; 2.77(\mathrm{~m}, 1 \mathrm{H})$; $2.91(\mathrm{~m}, 1 \mathrm{H}) ; 3.0(\mathrm{~d}, 1 \mathrm{H}, \mathrm{J}=14.4) ; 3.14(\mathrm{~m}, 1 \mathrm{H}) ; 3.24(\mathrm{~m}, 1 \mathrm{H}) ; 4-4.4(\mathrm{~m}, 9 \mathrm{H}) ; 4.72(\mathrm{~m}, 1 \mathrm{H}) ; 6.31$ $(\mathrm{m}, 2 \mathrm{H}) ; 6.27(\mathrm{~s}, 1 \mathrm{H}) ; 6.37(\mathrm{~s}, 1 \mathrm{H}) ; 6.89(\mathrm{~m}, 1 \mathrm{H}) ; 7.31(\mathrm{~d}, 1 \mathrm{H}, \mathrm{J}=8) .{ }^{13} \mathrm{C}-\mathrm{NMR} \delta: 13.9,14.0,16.1,16.4$, 18.2, 18.3, 18.4, 19.1, 20.4, 28.0, 28.6, 30.1, 30.3, 31.0, 35.3, 37.5, 39.2, 46.9, 51.1, 55.6, 56.5, 57.9, 58.5, 59.6, 59.8, 61.0, 61.2, 108.6, 142.3, 156.0, 157.5, 170.1, 171.1, 171.2, 173.4, 174.6. The product was not isolated in sufficiently pure form for elemental analysis and to measure the specific rotation.

\subsection{1-[(6-ethoxy-(5S)-isopropyl-(2R)-methyl-2,3,4,5-tetrahydro-3-oxo-pyrazin-2-yl)-(2S)-} isopropyl-3-aza-4-oxo-pentanoyl]-(2R)-[6-ethoxy-(5S)-isopropyl-(2R)-methyl-2,3,4,5 tetrahydro-3-oxo-pyrazin-2-yl)-4-aza-5-oxo-pentanoyl]-2-methyl-4-methylenepyrrolidine. (12b)

It was obtained by reacting 10b with 7 in the presence of DMTMM and following the procedure described for $\mathbf{8}$. The crude reaction product was submitted to silica gel chromatography eluting with hexane/ethyl acetate and the product was recovered as an oil in $70 \%$ yield.

${ }^{1} \mathrm{H}-\mathrm{NMR} \delta: 0.87(\mathrm{~d}, 3 \mathrm{H}, \mathrm{J}=6.9) ; 0.90(\mathrm{~d}, 3 \mathrm{H}, \mathrm{J}=6.9) ; 1.0(\mathrm{~m}, 12 \mathrm{H}) ; 1.29(\mathrm{~m}, 9 \mathrm{H}) ; 1.39(\mathrm{~s}, 3 \mathrm{H}) ; 1.47$ $(\mathrm{s}, 3 \mathrm{H}) ; 1.6(\mathrm{~m}, 2 \mathrm{H}) ; 2.0(\mathrm{~m}, 3 \mathrm{H}) ; 2.33(\mathrm{~m}, 2 \mathrm{H}) ; 2.53$ (d,1H,J=15.3); 2.63 (d,1H,J=14.4); 2.99 (d,1H, $\mathrm{J}=14.4) ; 3.02(\mathrm{~d}, 1 \mathrm{H}, \mathrm{J}=15.3) ; 3.2(\mathrm{~m}, 2 \mathrm{H}) ; 4-4.2(\mathrm{~m}, 8 \mathrm{H}) ; 4.56(\mathrm{~d}, 1 \mathrm{H}, \mathrm{J}=14.4) ; 5.04(\mathrm{bs}, 2 \mathrm{H}) ; 5.82$ $(\mathrm{s}, 1 \mathrm{H}) ; 5.87(\mathrm{~s}, 1 \mathrm{H}) ; 6.64(\mathrm{~m}, 1 \mathrm{H}) ; 7.30(\mathrm{~d}, 1 \mathrm{H}, \mathrm{J}=7.7) .{ }^{13} \mathrm{C}-\mathrm{NMR} \delta: 13.9,14.0,16.1,16.4,18.1,18.2$, 18.7, 21.5, 24.3, 27.7, 28.3, 30.2, 30.3, 30.9, 37.6, 39.3, 46.0, 46.4, 52.9, 57.1, 57.8, 58.4, 59.7, 60.9, $61.0,68.0,108.3,141.0,155.7,157.4,170.8,171.5,172.4,173.3,174.6$. The product was not isolated in sufficiently pure form for elemental analysis and to measure the specific rotation.

2.5. (2R,2'S,6'R,9'S,6' $S, 9$ '' $S)$-1-(6'-acetamido-3,8-diaza-10-carboxyethyl-2',9'-diisopropyl4,7-dioxo-6'-methyl-decan-1-yl)-2-(6'"-acetamido-2,8-diaza-10-carboxyethyl-9'"-isopropyl-7oxo-6"'-methyl-decan-1-yl)-4-methylenepyrrolidine. (2a) 
It was obtained starting from the intermediate 12a and following the procedure described for $\mathbf{1}$. The crude reaction product was purified by silica gel chromatography eluting with hexane/ethyl acetate. The pure product was obtained as a wax in $75 \%$ overall yield.

${ }^{1} \mathrm{H}-\mathrm{NMR} \delta$ : $0.96(\mathrm{~m}, 18 \mathrm{H}) ; 1.30(\mathrm{~m}, 6 \mathrm{H}) ; 1.58(\mathrm{~s}, 3 \mathrm{H}) ; 1.74(\mathrm{~s}, 3 \mathrm{H}) ; 2.05(\mathrm{~s}, 3 \mathrm{H}) ; 2.09(\mathrm{~s}, 3 \mathrm{H}) ; 1.6-2.3$ $(\mathrm{m}, 7 \mathrm{H}) ; 2.55(\mathrm{~d}, 1 \mathrm{H}, \mathrm{J}=14.8) ; 2.84(\mathrm{~m}, 3 \mathrm{H}) ; 3.09(\mathrm{~d}, 1 \mathrm{H}, \mathrm{J}=14.8) ; 3.5(\mathrm{~m}, 1 \mathrm{H}) ; 4.03-4.45(\mathrm{~m}, 8 \mathrm{H}) ; 4.50$ $(\mathrm{dd}, 1 \mathrm{H}, \mathrm{J}=4.8,8.4) ; 4.67(\mathrm{dd}, 1 \mathrm{H}, \mathrm{J}=4,8.4) ; 5.03(\mathrm{~m}, 2 \mathrm{H}) ; 6.56(\mathrm{~s}, 1 \mathrm{H}) ; 6.75(\mathrm{~d}, 1 \mathrm{H}, \mathrm{J}=8.4) ; 7.15$ $(\mathrm{m}, 1 \mathrm{H}) ; 7.91(\mathrm{~s}, 1 \mathrm{H}) ; 7.97(\mathrm{~d}, 1 \mathrm{H}, \mathrm{J}=7.4) ; 8.14(\mathrm{~d}, 1 \mathrm{H}, \mathrm{J}=8.4) .{ }^{13} \mathrm{C}-\mathrm{NMR} \delta: 14.8,18.9,19.0,19.3,19.7$, 19.9, 23.1, 23.4, 24.1, 24.9, 31.2, 32.2, 32.4, 35.0, 37.4, 40.7, 42.6, 53.0, 58.9, 59.5, 59.8, 61.1, 61.7,

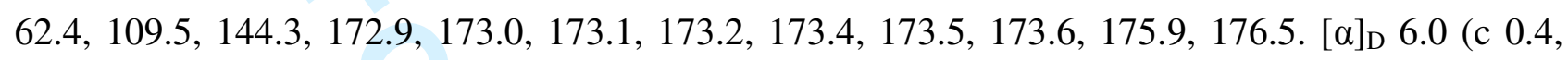
$\mathrm{CH}_{3} \mathrm{OH}$ ). Anal. Calcd. for $\mathrm{C}_{40} \mathrm{H}_{67} \mathrm{~N}_{7} \mathrm{O}_{11}$ : C,58.45; H,8.22; N,11.93. Found: C,58.61; H,8.2; N,11.95.

\section{6. (2R,2'S,6'R,9'S,6''S,9''S)-1-(6'-acetamido-3,8-diaza-10-carboxyethyl-2',9'-diisopropyl-} 4,7-dioxo-6'-methyl-decan-1-yl)-2-(6'"-acetamido-2,8-diaza-10-carboxyethyl-9'"-isopropyl-7oxo-6"'-methyl-decan-1-yl)-2-methyl-4-methylenepyrrolidine. (2b)

It was obtained starting from the intermediate $\mathbf{1 1 b}$ and following the procedure described for $\mathbf{1}$. The crude reaction product was purified by silica gel chromatography eluting with hexane/ethyl acetate. The pure product was obtained as a wax in $73 \%$ overall yield.

${ }^{1} \mathrm{H}-\mathrm{NMR} \delta$ : $0.93(\mathrm{~m}, 18 \mathrm{H}) ; 1.25(\mathrm{~d}, 3 \mathrm{H}, \mathrm{J}=7.2) ; 1.29(\mathrm{t}, 3 \mathrm{H}, \mathrm{J}=7.2) ; 1.54(\mathrm{~s}, 3 \mathrm{H}) ; 1.57(\mathrm{~s}, 3 \mathrm{H}) ; 1.74(\mathrm{~s}$, $3 \mathrm{H}) ; 2.03(\mathrm{~s}, 3 \mathrm{H}) ; 2.08(\mathrm{~s}, 3 \mathrm{H}) ; 1.4-2.3(\mathrm{~m}, 6 \mathrm{H}) ; 2.43(\mathrm{~d}, 1 \mathrm{H}, \mathrm{J}=15) ; 2.52(\mathrm{~d}, 1 \mathrm{H}, \mathrm{J}=15) ; 2.72(\mathrm{~m}, 1 \mathrm{H}) ;$ $2.87(\mathrm{~d}, 1 \mathrm{H}, \mathrm{J}=15) ; 2.97(\mathrm{~d}, 1 \mathrm{H}, \mathrm{J}=15) ; 3.63(\mathrm{~m}, 2 \mathrm{H}) ; 4-4.6(\mathrm{~m}, 9 \mathrm{H}) ; 5.0(\mathrm{bs}, 2 \mathrm{H}) ; 6.4(\mathrm{~s}, 1 \mathrm{H}) ; 6.8$ $(\mathrm{d}, 1 \mathrm{H}, \mathrm{J}=8.4) ; 7.21(\mathrm{~m}, 1 \mathrm{H}) ; 8.09(\mathrm{~d}, 1 \mathrm{H}, \mathrm{J}=7.4) ; 8.22(\mathrm{~s}, 1 \mathrm{H},) ; 8.31(\mathrm{~d}, 1 \mathrm{H}, \mathrm{J}=9.2) .{ }^{13} \mathrm{C}-\mathrm{NMR} \delta: 14.0$, $17.4,17.5,18.4,19.1,19.2,20.9,23.1,23.6,23.9,24.2,29.5,30.8,31.3,31.8,39.4,42.6,46.2,52.6$, 56.8, 57.2, 57.5, 60.2, 60.5, 60.9, 61.1, 67.4, 108.4, 141.7, 169.5, 170.2, 171.2, 171.9, 172.1, 172.4, 173.2, 174.2, 174.6. $[\alpha]_{\mathrm{D}} 23$ (c 0.4, $\mathrm{CHCl}_{3}$ ). Anal. Calcd. for $\mathrm{C}_{41} \mathrm{H}_{69} \mathrm{~N}_{7} \mathrm{O}_{11}$ : C,58.59; H,8.32; N,11.73. Found: C,58.65; H,8.34; N,11.71. 